\title{
A First Study of the Virulence Potential of a Bacillus subtilis Isolate From Deep-Sea Hydrothermal Vent
}

\section{OPEN ACCESS}

Edited by:

Vincenzo Scarlato,

University of Bologna, Italy

Reviewed by:

Marcelo Brocchi,

Campinas State University, Brazil

Andrea Vannini,

University of Bologna, Italy

${ }^{*}$ Correspondence:

Li Sun

Isun@qdio.ac.cn

Specialty section: This article was submitted to Molecular Bacterial Pathogenesis, a section of the journal Frontiers in Cellular and Infection Microbiology

Received: 10 December 2018 Accepted: 13 May 2019 Published: 31 May 2019

Citation:

Gu H-J, Sun Q-L, Luo J-C, Zhang J and Sun $L$ (2019) A First Study of the Virulence Potential of a Bacillus subtilis Isolate From Deep-Sea Hydrothermal

Front. Cell. Infect. Microbiol. 9:183. doi: 10.3389/fcimb.2019.00183

\begin{abstract}
Han-Jie Gu ${ }^{1,2,3}$, Qing-Lei Sun ${ }^{1,2}$, Jing-Chang Luo ${ }^{1,2,3}$, Jian Zhang ${ }^{1,2}$ and Li Sun ${ }^{1,2 *}$
${ }^{1}$ CAS Key Laboratory of Experimental Marine Biology, Center for Ocean Mega-Science, Institute of Oceanology, Chinese Academy of Sciences, Qingdao, China, ${ }^{2}$ Laboratory for Marine Biology and Biotechnology, Pilot National Laboratory for Marine Science and Technology, Qingdao, China, ${ }^{3}$ College of Earth and Planetary Sciences, University of Chinese Academy of Sciences, Beijing, China
\end{abstract}

Bacillus subtilis is the best studied Gram-positive bacterium, primarily as a model of cell differentiation and industrial exploitation. To date, little is known about the virulence of B. subtilis. In this study, we examined the virulence potential of a B. subtilis strain (G7) isolated from the Iheya North hydrothermal field of Okinawa Trough. G7 is aerobic, motile, endospore-forming, and requires $\mathrm{NaCl}$ for growth. The genome of $\mathrm{G} 7$ is composed of one circular chromosome of 4,216,133 base pairs with an average GC content of $43.72 \%$. G7 contains 4,416 coding genes, $27.5 \%$ of which could not be annotated, and the remaining $72.5 \%$ were annotated with known or predicted functions in 25 different COG categories. Ten sets of 23S, 5S, and 16S ribosomal RNA operons, 86 tRNA and 14 sRNA genes, 50 tandem repeats, 41 mini-satellites, one microsatellite, and 42 transposons were identified in G7. Comparing to the genome of the B. subtilis wild type strain NCIB $3610^{\top}$, G7 genome contains many genomic translocations, inversions, and insertions, and twice the amount of genomic Islands (Gls), with $42.5 \%$ of Gl genes encoding hypothetical proteins. G7 possesses abundant putative virulence genes associated with adhesion, invasion, dissemination, anti-phagocytosis, and intracellular survival. Experimental studies showed that G7 was able to cause mortality in fish and mice following intramuscular/intraperitoneal injection, resist the killing effect of serum complement, and replicate in mouse macrophages and fish peripheral blood leukocytes. Taken together, our study indicates that $G 7$ is a $B$. subtilis isolate with unique genetic features and can be lethal to vertebrate animals once being introduced into the animals by artificial means. These results provide the first insight into the potential harmfulness of deep-sea B. subtilis.

Keywords: Bacillus subtilis, deep-sea, hydrothermal vent, virulence, genome

\section{INTRODUCTION}

Bacillus species are aerobic, rod-shaped bacteria that stain Gram-positive or Gram-negative (Cote et al., 2015). They form spores that are resistant to cold, heat, and common disinfectants, thus enabling the bacteria to survive in various environments (Brown, 2000; Cote et al., 2015). Bacillus is a large genus with more than 200 species (Euzéby, 1997). The majority of Bacillus are non-pathogenic, and many species have been used for biotechnological and industrial applications (Hou et al., 2005; Price et al., 2007). Only a few species of Bacillus are known to cause disease 
in animals and humans (Spencer, 2003). Two Bacillus species, i.e., Bacillus anthracis and Bacillus cereus, are considered medically significant; $B$. anthracis is the etiologic agent of anthrax, a common disease of livestock, while $B$. cereus can cause food poisoning as well as local and systemic infections (Spencer, 2003; Schoeni and Wong, 2005; Hoffmaster et al., 2006; Ramarao and Sanchis, 2013). In addition, Bacillus licheniformis has been reported to be associated with foodborne illness (Logan, 2012), and Bacillus thuringiensis is an important insect pathogen (Nielsen-LeRoux et al., 2012).

Members of the genus Bacillus are found in diverse environments on earth including deep sea (D'Hondt et al., 2004; Batzke et al., 2007). In the deep sea hydrothermal areas, a wide range of microbes colonize, which can be free living and utilize the inorganic carbon and sulfides in the hydrothermal fields, or form various communities with host animals (Galéron, 2014). Several studies have indicated the existence of Bacillus species in deep sea (Marteinsson et al., 1996; Liu et al., 2006; Kurata et al., 2015; Wen et al., 2015). A report showed that, of the many isolates obtained from four different deep sea sediments, the vast majority (90\%) were spore-forming bacteria related to Bacillus (Sass et al., 2008). Another report showed that Grampositive, spore-forming piezophilic bacteria probably constituted a large part of cultivable deep-sea floor bacterial communities at Site C0020 off the Shimokita Peninsula, Japan, and the most abundant bacteria were members of Bacillales (Fang et al., 2017). In addition to being ubiquitous in deep-sea water and sediments, Bacillus species are shown to be present in and on marine organisms, such as sponges, ascidian, and crabs (Ivanova et al., 1999). However, to our knowledge, experimental studies on the virulence potential of Bacillus from deep sea have not been documented.

In this work, we reported the characterization of a B. subtilis strain, G7, isolated from the deep-sea hydrothermal field in Iheya North of Okinawa Trough. We analyzed the morphological, phylogenetic, genomic, and potential virulence of strain G7, and provided the first insight into the detrimental effect of Bacillus species from deep-sea hydrothermal vent.

\section{MATERIALS AND METHODS}

\section{Ethics Statement}

Experiments involving live animals conducted in this study were approved by the Ethics Committee of Institute of Oceanology, Chinese Academy of Sciences. All methods were carried out in accordance with the relevant guidelines, including any relevant details.

\section{Experimental Animals}

Clinically healthy turbot (Scophthalmus maximus) and halfsmooth tongue sole (Cynoglossu semilaevis) were purchased from a commercial fish farm in Shandong Province, China and maintained at $20^{\circ} \mathrm{C}$ in aerated seawater. Fish were acclimatized in the laboratory for 2 weeks before experimental manipulation. Before experiment, fish were confirmed to be clinically healthy as reported previously ( $\mathrm{Hu}$ et al., 2014) by confirmation of no bacterial presence in liver, kidney, and spleen. For tissue collection, fish were euthanized with an overdose of MS222 (tricaine methanesulfonate) (Sigma, St. Louis, USA) as reported previously (Wang et al., 2009). BALB/c mice (female, 8-10 weeks, and $14 \pm 2 \mathrm{~g}$ ) were obtained from Qingdao Daren Fortune Animal Technology Co., Ltd.. Before experiment, mice were acclimatized in laboratory for $7 \mathrm{~d}$ under good laboratory condition (temperature $25 \pm 2^{\circ} \mathrm{C}$, relative humidity $50 \pm 20 \%$, unlimited access to standard pellet food and tap water, and a dark and light cycle of 12/12) as reported previously (Khasawneh et al., 2015). For tissue collection, mice were anesthetized with ketamine (80 mg/kg) (Ketavet, Pfizer, Berlin, Germany) (Dietert et al., 2017).

\section{Bacterial Strains and Culture Conditions}

Bacillus subtilis subsp. subtilis NCIB $3610^{\mathrm{T}}$ (CGMCC accession No. 1.3358) and Bacillus subtilis subsp. subtilis 168 (CGMCC accession No. 1.1390) were purchased from China General Microbiological Culture Collection Center (CGMCC, http:// www.cgmcc.net).

\section{Isolation of G7}

Strain G7 was isolated from seawater sample collected at the Iheya North hydrothermal field $\left(126^{\circ} 53.84^{\prime} \mathrm{E}, 27^{\circ} 47.44^{\prime} \mathrm{N}\right.$, depth of $966.9 \mathrm{~m}$, temperature of $\left.4 \sim 5^{\circ} \mathrm{C}\right)$ in Okinawa Trough, northwestern Pacific Ocean. The seawater samples were obtained by a sample bottle (Sea-Bird O.T.E. Model 110, USA) on the Remotely Operated Vehicle (ROV) equipped on the KEXUE vessel (Tollefson, 2014). In situ temperature was measured using a conductivity-temperature-depth sampler. Seawater samples collected in situ were brought on board under totally enclosed condition and the outer surface of the sampling bottle was immediately disinfected with $75 \%$ alcohol before taking the water from the bottle; after being taken from the sampling bottle, the seawater was immediately used for bacterial isolation in an ultraclean workbench on board as follows: $100 \mu \mathrm{l}$ of the seawater was plated on marine agar 2216E medium (Sun et al., 2015) in an aseptic environment and incubated under aerobic conditions at $4^{\circ}, 15^{\circ}, 28^{\circ}$, or $40^{\circ} \mathrm{C}$ for $7 \mathrm{~d}$. The colonies on the plates were screened by their shape, size, margin, color, and opacity (Valiente Moro et al., 2013). Each type of colonies was selected for purification. Ninety-six bacterial isolates were obtained, and one of which was named G7. The purified isolates were resuspended in marine $2216 \mathrm{E}$ medium containing $30 \%(\mathrm{v} / \mathrm{v})$ glycerol and stored at $-80^{\circ} \mathrm{C}$.

\section{Phenotypic Analysis of G7}

In order to determine the temperature range of growth for G7, G7 was cultured in marine $2216 \mathrm{E}$ medium at $4^{\circ}, 20^{\circ}, 37^{\circ}, 50^{\circ}$, or $60^{\circ} \mathrm{C}$ for $72 \mathrm{~h}$. To determine the optimal growth temperature, the growth of G7 as well as B. subtilis subsp. subtilis NCIB $3610^{\mathrm{T}}$ was determined at $16^{\circ}, 28^{\circ}, 37^{\circ}$, and $50^{\circ} \mathrm{C}$. To determine $\mathrm{NaCl}$ dependence, G7 was cultured at $28^{\circ} \mathrm{C}$ in marine $2216 \mathrm{E}$ medium containing different concentrations of $\mathrm{NaCl}(0-10 \%$, at intervals of $0.5 \%)$. The $\mathrm{pH}$ range was determined from $\mathrm{pH}$ 4.0-11.0 (at intervals of $1.0 \mathrm{pH}$ unit) using the buffer system described previously (Xu et al., 2005) in marine 2216E medium. Gram staining and spore morphology were analyzed using a 
Gram-staining kit and a spore staining kit (Haibo, Qingdao, China), respectively. Oxidase activity was determined using Oxidase reagent (Haibo, Qingdao, China); catalase activity was determined by bubble formation in a $10 \%(\mathrm{v} / \mathrm{v}) \mathrm{H}_{2} \mathrm{O}_{2}$ solution.

\section{Motility Assay and Flagella Observation}

Motility assay was performed as reported previously (Mi et al., 2015; Sun et al., 2016). Briefly, G7 was cultured in marine $2216 \mathrm{E}$ medium to an $\mathrm{OD}_{600}$ of 0.8 , and $5 \mu \mathrm{l}$ of cell suspension was spotted onto the center of $2216 \mathrm{E}$ medium plates containing $0.3 \%$ or $0.5 \%(\mathrm{w} / \mathrm{v})$ agar. The plates were incubated at $28^{\circ} \mathrm{C}$ for $24 \mathrm{~h}$, and the motility of the bacteria was observed. For flagella observation, G7 was grown in solid marine agar $2216 \mathrm{E}$ medium for $24 \mathrm{~h}$, followed by fixation with glutaraldehyde and dehydration with acetone. The cells were then observed with a transmission electron microscopy (TEM) (Hitachi, JEM-2100, Japan) as reported previously (Sun and Sun, 2016). The assays were performed three times.

\section{Phylogenetic Analysis}

The phylogenetic tree was constructed based on the core genes of 18 Bacillus sp. strains with available genome sequences (Table S1); the core genes of the 18 genomes were obtained using cd-hit 4.6.1 (Huang et al., 2010), and the corresponding protein sequences were aligned with MUSCLE 3.8.31 (Edgar, 2004); phylogenetic trees were generated with Treebest 1.9.2 (Caputo et al., 2015). The average nucleotide identity (ANI) values were calculated with EzBioCloud ANI calculator (https:// www.ezbiocloud.net/tools/ani).

\section{Genome Sequencing and Analysis}

The genomic DNA of G7 was extracted using a Bacteria DNA extraction kit (TIANGEN Biotech, Beijing, China). Genome sequencing was conducted by Novogene (Beijing, China). The sequencing was performed using the third-generation PacBio RSII platform (Pacific Biosciences, Menlo Park, USA) with $10 \mathrm{~Kb}$ SMRT Bell libraries, and $1.11 \mathrm{~Gb}$ clean data were acquired after filtering out the low-quality reads. The reads were assembled using SMRT portal assembly software (Berlin et al., 2015). Putative coding sequences were identified using GeneMarkS software (http://topaz.gatech.edu/GeneMark) (Besemer et al., 2001). Genes encoding virulence factors were identified with Virulence Factors of Pathogenic Bacteria Database (VFDB) (Chen et al., 2005). Repeated sequences were predicted with RepeatMasker (Saha et al., 2008) and TRF (Benson, 1999). rRNAs, sRNAs, and tRNAs were predicted by using RNAmmer (Lagesen et al., 2007), Rfam (Gardner et al., 2009), and tRNAscan-SE (Lowe and Eddy, 1997), respectively. The functional annotation was carried out using the BLASTP search tool (Altschul et al., 1990) and KEGG (Kyoto encyclopedia of genes and genomes; http://www.genome. jp/kegg/) (Kanehisa et al., 2004), COG (http://www.ncbi.nlm. nih.gov/COG/) (Tatusov et al., 2003), SwissProt (http://www. uniprot.org/) (Bairoch and Apweiler, 2000), GO (Gene Ontology; http://www.geneontology.org/) (Ashburner et al., 2000), and GenBank's non-redundant protein (nr) (NCBI non-redundant database; http://www.ncbi.nlm.nih.gov/RefSeq/) (Li et al., 2002) databases (parameters: minimal alignment length percentage $\geq 40 \%$, identity $\geq 40 \%$, e-value $\leq 1 \mathrm{e}-5$ ). Gene Islands (GIs) were predicted with IslandPath-DIOMB (parameters: e-value $=0.001$, mobility gene $\geq 1$ ) (Hsiao et al., 2003). Genome mapping was generated with Circos (Krzywinski et al., 2009).

The genome sequences of G7 and B. subtilis subsp. subtilis NCIB $3610^{\mathrm{T}}$ were compared using MUMmer (Kurtz et al., 2004). Predicted proteins of G7 were compared with those of NCIB $3610^{\mathrm{T}}$, using BLASTP with an E-value cutoff of 1e-5. Orthologous proteins are defined as reciprocal best hit proteins with a minimum $40 \%$ identity and $70 \%$ of the length of the query protein, calculated with BLAST algorithm. Proteins without orthologs were considered to be specific proteins. COG function category was analyzed by searching all predicted proteins against the COG database on the basis of the BLASTP.

\section{In vivo Infection and Virulence Assay}

To determine tissue dissemination, G7 and strain 168 were cultured to an $\mathrm{OD}_{600}$ of 0.8 at $28^{\circ} \mathrm{C}$ in marine $2216 \mathrm{E}$ and LB medium, respectively; the cells were washed with PBS and resuspended in PBS to $1 \times 10^{6} \mathrm{CFU} / \mathrm{ml}$. Turbot and mice were inoculated via intramuscular (i.m., for fish) and intraperitoneal (i.p., for mice) injection with $100 \mu \mathrm{l} \mathrm{G7}$ or strain 168 suspension. At 12,24 , and $48 \mathrm{~h}$ post-infection (hpi), blood, liver, and spleen were taken aseptically from fish ( 5 fish/time point) and mice (3 animals/time point). The tissues were homogenized in a homogenizer (Jingxin, Shanghai, China) containing PBST (PBS with $1 \%$ Triton X-100) (100 $\mu \mathrm{l} / \mathrm{mg}$ tissue). The homogenates were diluted serially and plated in triplicate on marine agar $2216 \mathrm{E}$ plates or LB plates. The plates were incubated at $28^{\circ} \mathrm{C}$ for $24 \mathrm{~h}$, and the colonies that appeared on the plates were enumerated. To determine median lethal dose $\left(\mathrm{LD}_{50}\right), \mathrm{G} 7$ was cultured in marine $2216 \mathrm{E}, \mathrm{NCIB} 3610^{\mathrm{T}}$ and strain 168 were cultured in LB, and resuspended in PBS. Fish and mice were divided randomly into groups of 20 fish or 10 mice; each group was infected via i.m. (for fish) or i.p. (for mice) injection with $100 \mu \mathrm{l}$ bacterial suspension containing $10^{4}$ to $10^{9} \mathrm{CFU}$ (at 10 -fold difference) of bacterial cells. The animals were monitored for mortality for 14 days, and $\mathrm{LD}_{50}$ was determined with Probit analysis tool of the SPSS 17.0 software (SPSS Inc., USA). All experiments were conducted in three replicates.

\section{Serum Survival and Hemolytic Activity Assay}

Serum survival analysis was performed as reported previously (Wang et al., 2013). To examine hemolytic activity tests were checked on 2\% rabbit blood (Hope Bio, Qingdao, China) agar plates. G7, NCIB $3610^{\mathrm{T}}$, and strain 168 were cultured in marine $2216 \mathrm{E}$ medium to an $\mathrm{OD}_{600}$ of 0.8 , and $10 \mu \mathrm{l}$ cell suspension was added onto a filter disc on a $2 \%$ rabbit blood (Hope Bio, Qingdao, China) agar plate. As controls, $0.2 \%$ Triton X-100 and PBS were also spotted similarly on the plate. The plate was incubated at $28^{\circ} \mathrm{C}$ for $24 \mathrm{~h}$ and observed for hemolytic halos.

\section{Intracellular Infection}

Intracellular infection was performed as reported previously (Sui et al., 2017). Briefly, for infection of RAW264.7 cells, G7, 


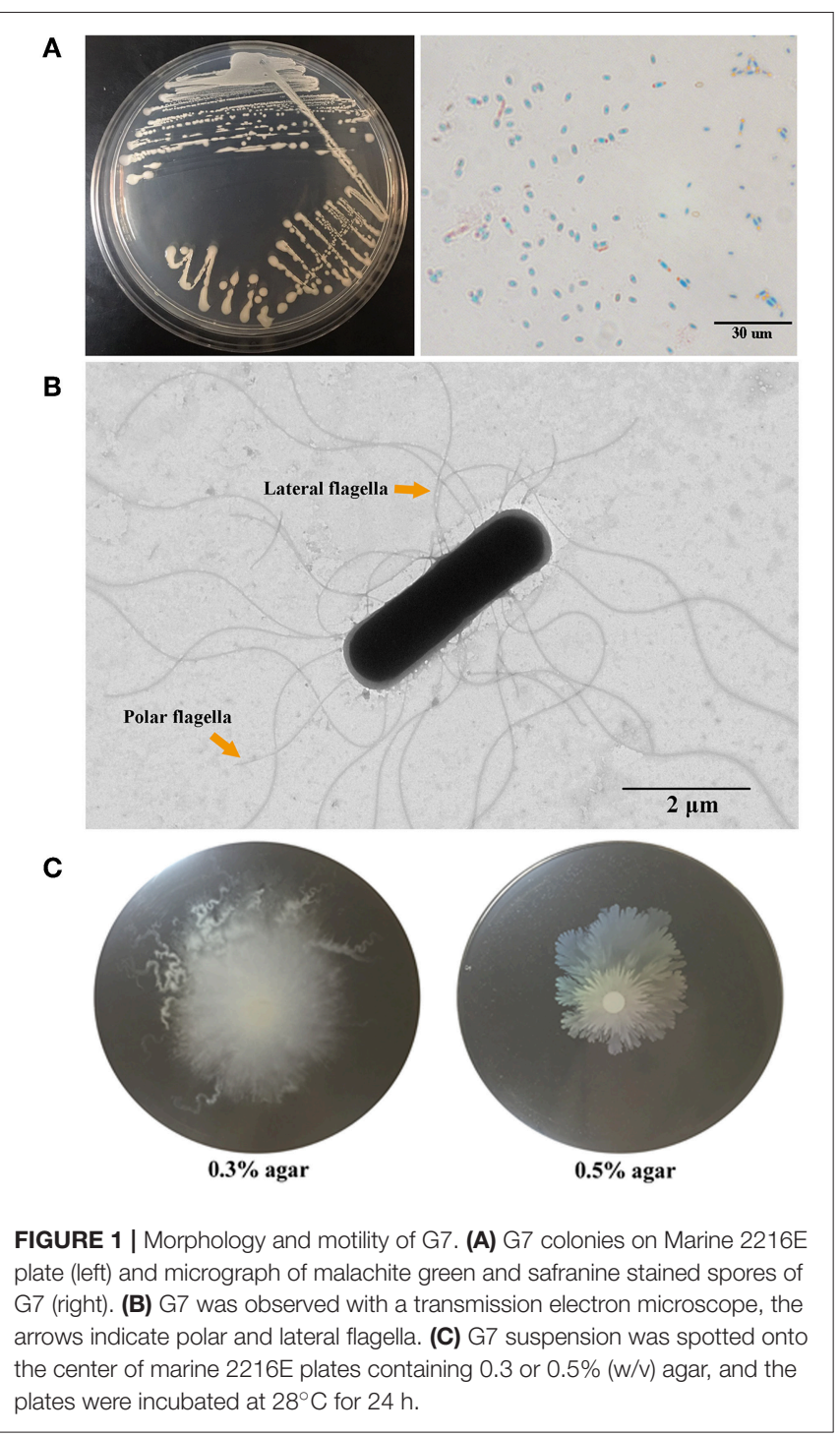

NCIB $3610^{\mathrm{T}}$, and strain 168 were cultured and resuspended in PBS as above; the bacteria were added to $100 \%$ confluent RAW264.7 cells (American Tissue Culture Collection, USA) in 24-well plates at a multiplicity of infection (MOI) of 10:1; the plates were centrifuged at $800 \mathrm{~g}$ for $10 \mathrm{~min}$ and incubated at $28^{\circ} \mathrm{C}$ for $2 \mathrm{~h}$. The cells were then washed three times with PBS and incubated with fresh medium containing $200 \mu \mathrm{g} / \mathrm{ml}$ gentamicin (Thermo Scientific HyClone, Beijing, China) for $1 \mathrm{~h}$ to kill the extracellular bacteria. The medium was then removed, and fresh medium containing $10 \mu \mathrm{g} / \mathrm{ml}$ gentamicin was added to the cells. For the remaining experiment, the concentration of gentamicin in the culture medium was maintained at $10 \mu \mathrm{g} / \mathrm{ml}$, and the plates were incubated at $28^{\circ} \mathrm{C}$ for $0,2,4,6$, and $8 \mathrm{~h}$. For cell number counting, at each time point of incubation, fresh medium was added to the plates $(500 \mu \mathrm{l} /$ well $)$, and the cells on the plates were scraped with a cell scraper (Costar, Corning, NY) for cell counting. For the determination of intracellular bacterial number, $500 \mu \mathrm{l} 1 \%(\mathrm{v} / \mathrm{v})$ Triton X-100 was added to the cells in each well of the plate to lyse the cells, and the lysate was diluted and plated onto marine 2216E agar plates, which were incubated at $28^{\circ} \mathrm{C}$ for $24 \mathrm{~h}$, and colonyforming units (CFUs) were counted. For infection of turbot peripheral blood leukocytes (PBLs), PBLs were prepared and cultured in L-15 medium (Thermo Scientific HyClone, Beijing, China) as reported previously (Liu et al., 2010) in 96-well culture plates $\left(10^{5}\right.$ cells/ well). Intracellular infection of G7 in PBLs was performed as above. All experiments were performed three times.

\section{Microscopy}

To prepare fluorescent bacteria, $500 \mu \mathrm{l}$ of G7 suspension $(1 \times$ $10^{8} \mathrm{CFU} / \mathrm{ml}$ ) was incubated with $5 \mu \mathrm{M}$ CFDA-SE (US Everbright Inc, Suzhou, China) at $37^{\circ} \mathrm{C}$ for $20 \mathrm{~min}$, followed by incubation with $5 \%$ BSA for $20 \mathrm{~min}$. The bacteria were then washed three times with PBS. For infection, Raw264.7 cells were cultured to $100 \%$ confluence in $35 \mathrm{~mm}$ confocal dishes (Nest, China); turbot PBLs were added to $35 \mathrm{~mm}$ confocal dishes (Nest, China) to $5 \times$ $10^{6}$ cells $/ \mathrm{ml}$. The cells were then infected with G7 for 2,4 , and $6 \mathrm{~h}$ as above. At each time point, the cells were extensively washed with PBS and stained with Hoechst 33258 (Beyotime, Shanghai, China) for $30 \mathrm{~min}$ at room temperature. The cells were washed as above, and extracellular fluorescence was quenched by adding $1 \mathrm{ml} 0.125 \%$ trypan blue in PBS, followed by incubation at $28^{\circ} \mathrm{C}$ for $30 \mathrm{~min}$. The cells were washed as above and observed with a confocal microscope (Carl Zeiss LSM710, Germany).

\section{Statistical Analysis}

All experiments were performed at least three times, and statistical analyses were carried out with SPSS 17.0 software (SPSS Inc., Chicago, USA). Data were analyzed with analysis of variance (ANOVA), and statistical significance was defined as $P<0.05$.

\section{Database Accession Number}

The whole genome sequence of G7 has been deposited in GenBank under the accession number CP029609.

\section{RESULTS}

\section{Identification and Characterization of Bacillus subtilis subsp. subtilis G7}

Strain G7 was isolated from the deep-sea water collected from Iheya North hydrothermal field. G7 was aerobic, motile, gram-positive, and oxidase- and catalase-positive; it required $\mathrm{NaCl}$ for growth and could grow at $\mathrm{NaCl}$ concentrations up to $8 \%$ (Figure S1). Visible growth occurred at temperatures between $20^{\circ}$ and $60^{\circ} \mathrm{C}$ within a period of 3 days and in the $\mathrm{pH}$ range of $5-11$. For G7, the optimal growths were observed at $50^{\circ}, 37^{\circ}$, and $28^{\circ} \mathrm{C}$, at which temperatures the cells grew much faster than at $16^{\circ} \mathrm{C}$; the growths at $50^{\circ}$ and $37^{\circ} \mathrm{C}$ were very similar and slightly faster than growth at $28^{\circ} \mathrm{C}$ (Figure S2). Similar to G7, NCIB $3610^{\mathrm{T}}$ grew optimally at $50^{\circ}, 37^{\circ}$, and $28^{\circ} \mathrm{C}$, with the best growth occurring at $37^{\circ} \mathrm{C}$, at which temperature the bacteria grew slightly faster than at $50^{\circ}$ and $28^{\circ} \mathrm{C}$ (Figure S2). Colonies on marine $2216 \mathrm{E}$ agar medium after $24 \mathrm{~h}$ growth at $28^{\circ} \mathrm{C}$ were smooth, round, white in color, and about $3 \pm 0.3 \mathrm{~mm}$ in diameter (Figure 1A, 

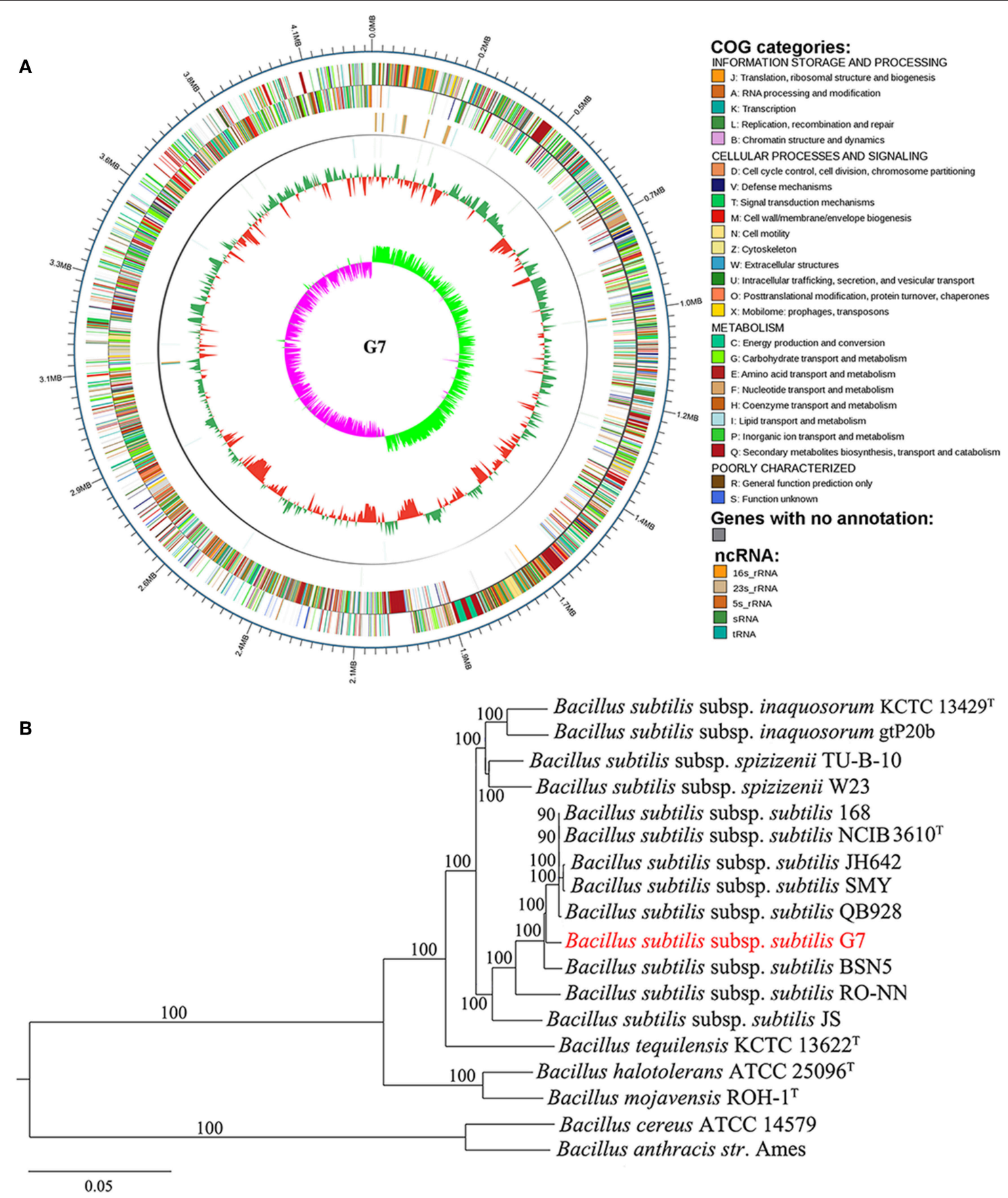

FIGURE 2 | Circle genome map (A) and core genome phylogeny (B) of G7. (A) The scale on the outside of the circles indicates the size of G7 genome; the chromosome is represented by circles ranging from 1 (outer) to 4 (inner). Circle 1, the genes annotated by COG database (indicated by colors other than gray) and genes with no annotation (indicated by gray color); Circle 2, ncRNA, with colors indicating different types of ncRNA as shown in the figure; Circle 3, GC content; Circle 4, GC skew. (B) Neighbor-joining tree was constructed based on 1,113 highly conserved orthologous genes of 18 annotated genomes of Bacillus. Each node number represents the percentage of bootstrap support from 1,000 resampled datasets. The scale bar represents 0.05 substitutions per site.

panel left). The cells produced endospores, which were oval and located centrally in unswollen sporangia (Figure 1A, panel right). G7 possesses polar and lateral flagella (Figure 1B), and could swim in $0.3 \%$ agar and swarm in $0.5 \%$ agar (Figure 1C).

\section{Phylogenetic Analysis of G7}

To facilitate the study of G7, the genome of this strain was sequenced (Figure 2A). Comparative average nucleotide identity (ANI) analysis with available bacterial genomes in Integrated Microbial Genomes (IMG) database showed that the genome 
of G7 is most closely related to that of many sequenced strains of $B$. subtilis subsp. subtilis, and the ANI values between strain G7 and these strains are all higher than the hypothesized species demarcation threshold value of 95\% (Table S2), which is generally accepted for species delineation (Richter and RossellóMóra, 2009). The 16S rRNA gene sequence similarity between strains G7 and B. subtilis subsp. subtilis QB928 is $99.80 \%$, which is clearly above the threshold (97\%) of 16S rRNA gene sequence similarity for species delineation (Richter and Rosselló-Móra, 2009). There are 1113 orthologous genes highly conserved in the members of 18 Bacillus species (Table S1) (Note: within these 18 Bacillus sp. strains, only a subset of sequenced $B$. subtilis subsp. subtilis strains were considered for analysis because the genome of different $B$. subtilis subsp. subtilis strains share high similarities; BSP1, 6051-HGW, BAB-1 and many other strains were not included in the analysis). In the genome tree based on the 1113 orthologous genes (Figure 2B), the B. subtilis species formed a group, which was separated from that formed by Bacillus cereus and Bacillus anthracis, and strain G7 was a member of B. subtilis subsp. subtilis.

TABLE 1 | General features of Bacillus subtilis subsp. subtilis G7.

\begin{tabular}{lc}
\hline Category & Characteristics \\
\hline Genome size (bp) & $4,216,133$ \\
GC content (\%) & 43.72 \\
Gene number & 4,416 \\
Coding region (bp) & $3,757,905$ \\
Coding percentage (\%) & 89.13 \\
Average gene length (bp) & 851 \\
Genes assigned to COG categories & 3,201 \\
tRNA genes & 86 \\
rRNA operons & 10 \\
Other regulatory ncRNAs & 14 \\
Genomic islands & 16
\end{tabular}

\section{General Features of the G7 Genome}

The general features of the G7 genome are summarized in Table 1 and Figure 2A. The genome is composed of one circular chromosome of 4,216,133 base pairs (bp) with an average GC content of $43.72 \%$. The coding region accounts for $89.13 \%$ of the chromosome and was predicted to contain 4,416 genes which are distributed along both strands. Of the 4,416 genes, 1,215 (27.5\%) could not be annotated; the remaining 3,201 (72.5\%) genes could be annotated with known or predicted functions in 25 different COG categories, including those for transcription (category $\mathrm{K}, 10.3 \%$ ), amino acid transport and metabolism (category $\mathrm{E}$, $10.15 \%$ ), carbohydrate transport and metabolism (category G, 9.74\%), translation, ribosomal structure and biogenesis (category J, 7.18\%), and cell wall/membrane/envelope biogenesis (category M, 7.06\%). Ten sets of 23S, 5S, and $16 \mathrm{~S}$ ribosomal RNA operons, 86 tRNA genes, and 14 sRNA (Table S3) were identified. The 10 rRNA operons exhibit very high similarity (>99.9\%). Sixteen Genomic Islands (GIs) were found in the genome (Table S4), comprising $236,853 \mathrm{bp}$ and $5.61 \%$ of the genome. The GIs vary very differently in size and gene content. G7 also contains 50 tandem repeat regions, $41 \mathrm{mini}$-satellites, one microsatellite, and 42 transposons.

\section{Comparative Genome Analysis Between G7 and its Close Homolog}

The genome of G7 was compared to that of its most closely related strain, B. subtilis subsp. subtilis NCIB $3610^{\mathrm{T}}$, which was proposed to be the true wild type strain (Srivatsan et al., 2008). G7 genome is smaller and devoid of the plasmid present in NCIB $3610^{\mathrm{T}}$ (Figure 3); the majority of genes in the two genomes exhibit strong collinearity and high sequence similarities; however, many genomic translocations, inversions, and insertions occur in G7 genome. G7 and NCIB $3610^{\mathrm{T}}$ share 3785 orthologous genes, accounting for 89.7 and $87.13 \%$ of all the genes of G7 and NCIB $3610^{\mathrm{T}}$, respectively, and contain 434 and 559 specific genes, respectively (Figure 4A). Among the 434 specific genes of G7, $146(33.6 \%)$ and $288(66.4 \%)$ were

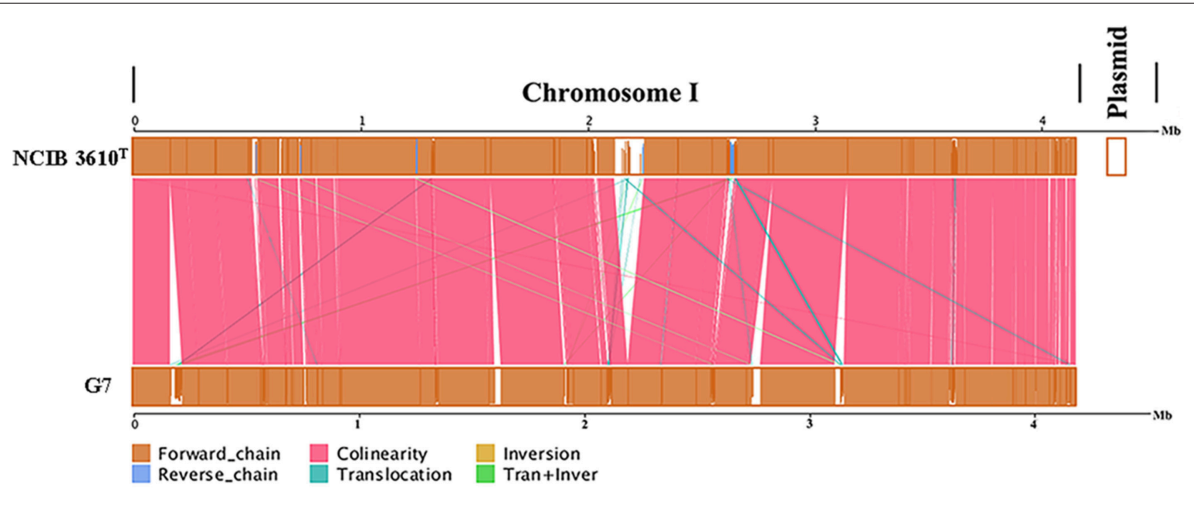

FIGURE 3 | Genome alignments for G7 and NCIB $3610^{\top}$ using MUMmer. Upper and lower axes of linear synteny graph are constructed after the same proportion of size reduction in length of both sequences. According to BLAST results, each pair nucleic acid sequence of the two alignments is marked in the coordinate diagram according to its position information, and the height of the filled color in the block indicates similarity of sequence alignment. The color of the lines between the two axes indicates the type of comparison. 


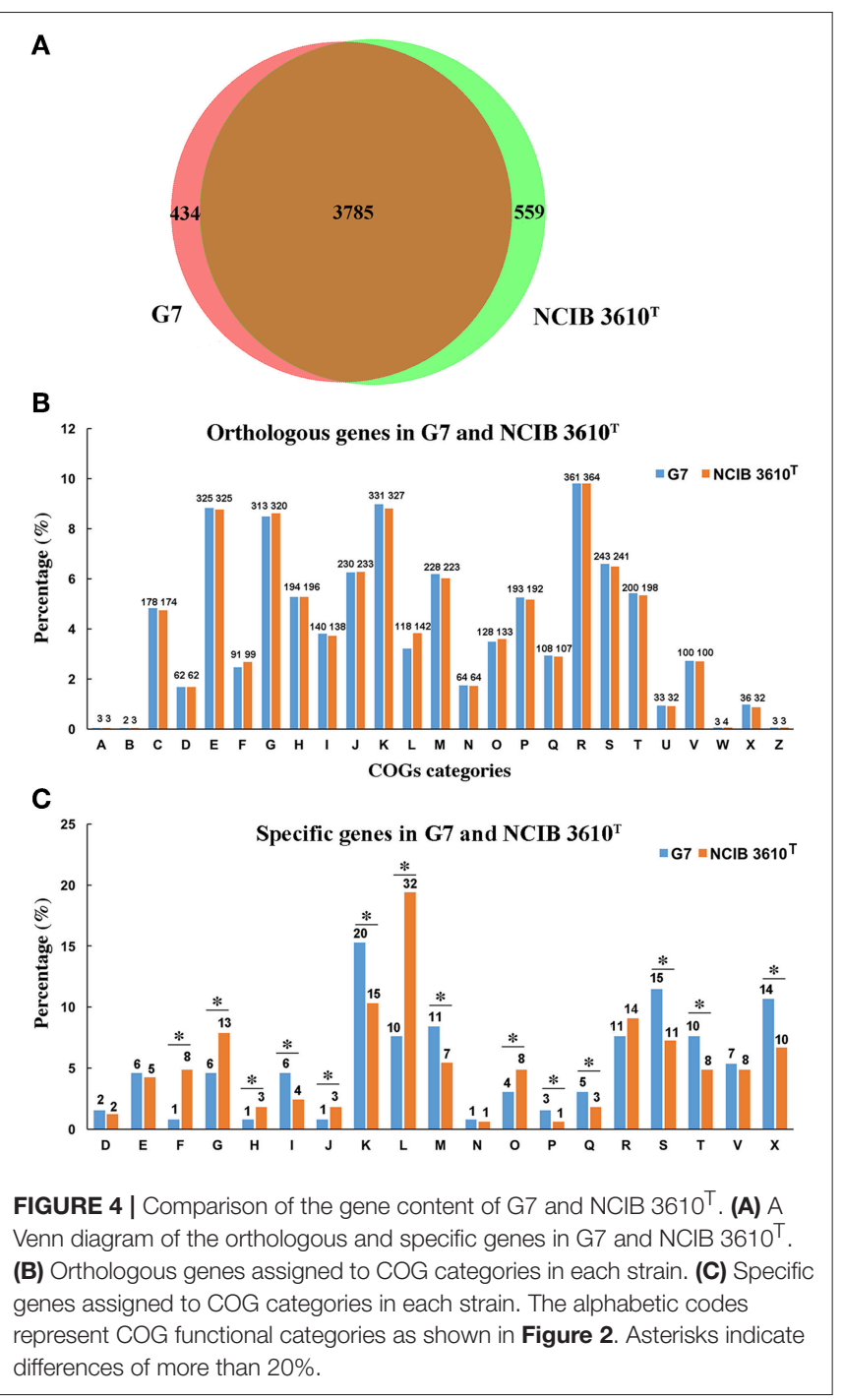

distributed in GIs and in "normal" coding regions, and no gene was found in repeated sequences. Most of the specific genes were annotated as hypothetical proteins and had no putative functions. Compared to NCIB $3610^{\mathrm{T}}$, which has 8 GIs, G7 has twice the amount of GIs. GI_02, GI_03, GI_05, GI_10, and GI_13 carry genes encoding integrases, transposases, or phage portal proteins, GI_06 and GI_16 contain genes encoding ABC transporters; however, no GI genes were predicted to be involved in virulence. Many genes (47\%) in the GIs of G7 are specific genes that do not have orthologs in $\operatorname{NCIB~} 3610^{\mathrm{T}}$, and more than 100 genes $(42.5 \%)$ were predicted to encode hypothetical proteins (Table S4). COG analysis revealed that the distributions of the orthologous genes of the two strains in the COG functional classes were similar with respect to the total numbers of proteincoding genes (Figure 4B). However, with respect to the genes unique to each strain, G7 has higher proportions of specific genes belonging to the COG categories of $\mathrm{K}$ (transcription), $\mathrm{S}$ (function unknown), X (mobilome: prophages, transposons), $\mathrm{M}$ (cell wall/membrane/envelope biogenesis), I (lipid transport and metabolism), T (signal transduction mechanism), Q (secondary metabolite biosynthesis, transport, and catabolism), and $\mathrm{P}$ (inorganic ion transport and metabolism). In addition, G7 possesses lower proportions of specific genes belonging to the COG categories of $\mathrm{F}$ (nucleotide transport and metabolism), $\mathrm{G}$ (carbohydrate transport and metabolism), H (coenzyme transport and metabolism), J (translation, ribosomal structure, and biogenesis), L (dna replication, recombination, and repair), and $\mathrm{O}$ (posttranslational modification, protein turnover, and chaperones) (Figure 4C).

\section{Virulence-Associated Genes in G7 Genome}

Many putative virulence genes were identified in G7 genome (Table 2), which were associated with toxins, adhesion, invasion, dissemination, anti-phagocytosis, and intracellular survival. All the predicted virulence genes in G7 are also present in the genome of $\mathrm{NCIB} 3610^{\mathrm{T}}$. Among the toxins are hlyIII (GM002238) encoding hemolysin III, and cylR2 encoding a protein similar to the virulence-contributing cytolysin of Enterococcus faecalis (Shankar et al., 2004). Among the adhesins are an adherence-related protein, endopeptidase $\mathrm{ClpC}$, and a homolog of the fibronectin-binding protein FbpA of Listeria monocytogenes, which is the adhesin responsible for infectivity (Osanai et al., 2013). The genetic organization of the capsule genes capA, capC, capB, and capD (GM003849-GM003851 and GM002061) in G7 is the same as that in B. anthracis str. Ames Ancestor (GenBank accession no. PRJNA10784), in which the cap operon is essential to virulence (Makino et al., 2002). G7 also possesses a hyaluronic acid capsule related gene (GM003824) similar to the hasC of Streptococcus pyogenes, which contributes to anti-phagocytosis, adherence, and tissue invasion (Ashbaugh et al., 1998; Bisno et al., 2003). Among the genes of the category of Intracellular Survival are lplA1 (GM001144), which encodes a lipoate protein ligase necessary for efficient intracellular proliferation of $L$. monocytogenes (O'Riordan et al., 2003); lspA (GM001724), which encodes a lipoprotein signal peptidase required for the intracellular multiplication and survival of Mycobacterium tuberculosis in macrophages (Rampini et al., 2008; Pathak et al., 2015); sodA (GM002170) and $\operatorname{sodB}$ (GM002589), which were important for the intracellular survival and transmission of M. tuberculosis and L. pneumophila (Sadosky et al., 1994; Smith, 2003). A number of genes associated with iron acquisition were found in G7, including enterobactin, mycobactin, pyoverdine, pyochelin, and Fe-transport operon (FbpABC) (Table 2), which are known to promote the growth and invasion of some pathogens (Strange et al., 2011; Cassat and Skaar, 2013; Poppe et al., 2018; Qi and Han, 2018).

Many other virulence factors have also been identified, such as aureolysin, which is known to facilitate serum resistance and the spread of pathogens (Labreuche et al., 2010; Zhou et al., 2015), MprA, MprB, and MprP, which are required for establishment and maintenance of persistent infection in M. tuberculosis (Zahrt and Deretic, 2001; Zahrt et al., 2003).

\section{Analysis of the Virulence Potential of G7 In vivo Virulence Analysis}

The $\mathrm{LD}_{50}$ of G7 in lower (turbot and tongue sole) and higher (mice) vertebrates were determined by i.m. (for fish) and i.p. 
TABLE 2 | Putative virulence factors of strain G7 and NCIB 3610 ${ }^{\top}$.

\begin{tabular}{|c|c|c|c|c|c|}
\hline $\begin{array}{l}\text { Virulence } \\
\text { genes }\end{array}$ & Annotation & $\begin{array}{l}\text { Gene ID } \\
\text { (G7) }\end{array}$ & $\begin{array}{l}\text { Identity } \\
(\%)\end{array}$ & $\begin{array}{c}\text { Gene ID } \\
(\text { NCIB 3610 })\end{array}$ & $\begin{array}{c}\text { Identity } \\
(\%)\end{array}$ \\
\hline \multicolumn{6}{|l|}{ TOXIN } \\
\hline hlylll & Hemolysin III & GM002238 & 69.31 & 002367 & 68.1 \\
\hline cylR2 & Cytolysin & GM001003 & 40.91 & 000972 & 40.9 \\
\hline \multicolumn{6}{|c|}{ ADHERENCE } \\
\hline$h t p B$ & Hsp60 & GM000708 & 84.44 & 000629 & 59.68 \\
\hline$f b p A$ & FbpA & GM001743 & 51.66 & 001707 & 52.2 \\
\hline$c / p C$ & ClpC & GM000091 & 78.98 & 000092 & 79 \\
\hline \multicolumn{6}{|l|}{ ESCAPE } \\
\hline capA & Capsule & GM003849 & 89.36 & 003872 & 88.21 \\
\hline capC & Capsule & GM003850 & 78.38 & 003873 & 79 \\
\hline$c a p B$ & Capsule & GM003851 & 83.7 & 003874 & 83.2 \\
\hline$c a p D$ & Capsule & GM002147 & 76 & 001999 & 78.1 \\
\hline сар8B & Capsule & GM003887 & 43.19 & 003789 & 42.8 \\
\hline сар8 J & Capsule & GM004394 & 43.27 & 004407 & 42.3 \\
\hline сар8D & Capsule & GM003681 & 54.3 & 003589 & 53.5 \\
\hline cpsD & Capsule & GM003682 & 42.94 & 003590 & 42.77 \\
\hline cpsE & Capsule & GM003814 & 40.51 & 003718 & 40.29 \\
\hline $\operatorname{cps} 41$ & Capsule & GM003820 & 63.51 & 003723 & 62.34 \\
\hline hasC & Hyaluronic acid capsule & GM003824 & 55.75 & 003843 & 63.2 \\
\hline \multicolumn{6}{|c|}{ INTRACELLULAR SURVIVAL } \\
\hline$|p| A 1$ & LplA1 & GM001144 & 65.26 & 001112 & 65.3 \\
\hline IspA & Lsp & GM001724 & 57.14 & 001688 & 57.1 \\
\hline panD & PanC/PanD & GM002304 & 53.78 & 002431 & 58.7 \\
\hline panC & PanC/PanD & GM002305 & 40.79 & 002432 & 43.7 \\
\hline SodA & SodA & GM002170 & 43.15 & 002105 & 45.7 \\
\hline SodB & SodB & GM002589 & 53.37 & 002710 & 53.4 \\
\hline \multicolumn{6}{|c|}{ IRON UPTAKE } \\
\hline$f b p C$ & FbpC & GM000152 & 40 & 002599 & 40.1 \\
\hline$f b p A$ & FbpA & GM001743 & 51.66 & 001707 & 52.2 \\
\hline fepC & Enterobactin & GM000858 & 46.99 & 000785 & 46.75 \\
\hline$f b p A B C$ & FbpABC & GM002478 & 40.08 & 002510 & 40.06 \\
\hline $\mathrm{mbtH}$ & Mycobactin & GM003430 & 56.45 & 003338 & 56.17 \\
\hline$p v d D$ & Pyoverdine & GM003431 & 43.21 & 003439 & 43.1 \\
\hline entB & Enterobactin & GM003432 & 48.83 & 003452 & 48.8 \\
\hline$p c h D$ & Pyochelin & GM003433 & 54.81 & 003453 & 60 \\
\hline entA & Enterobactin & GM003435 & 42.64 & 003343 & 42.32 \\
\hline \multicolumn{6}{|c|}{ GENERAL INFECTION } \\
\hline aur & Aureolysin & GM001636 & 46.98 & 001202 & 41.6 \\
\hline mprA & MprAB & GM001477 & 46.22 & 001381 & 45.75 \\
\hline mprB & MprAB & GM004336 & 40.54 & 001381 & 40.12 \\
\hline vscN & TTSS & GM001802 & 52.61 & 001691 & 51.92 \\
\hline$h s p R$ & HspR & GM001927 & 40.3 & 001891 & 40.3 \\
\hline $\operatorname{sig} A$ & SigA & GM002608 & 62.38 & 002730 & 50.5 \\
\hline relA & RelA & GM002831 & 44.35 & 002987 & 44.5 \\
\hline clpP & ClpP & GM003700 & 77.6 & 003727 & 76.71 \\
\hline ureA & Urease & GM003930 & 61.16 & 003951 & 61.5 \\
\hline ureB & Urease & GM003931 & 48.28 & 003952 & 49.1 \\
\hline ureC & Urease & GM003932 & 57.14 & 003952 & 56.2 \\
\hline narl & Nitrate reductase & GM003997 & 40.99 & 004021 & 43.1 \\
\hline narH & Nitrate reductase & GM003999 & 56.73 & 004023 & 59.1 \\
\hline narG & Nitrate reductase & GM004000 & 49.79 & 004024 & 50.1 \\
\hline
\end{tabular}

(for mice) infection. In comparison, the virulence potential of Bacillus subtilis subsp. subtilis NCIB $3610^{\mathrm{T}}$ and Bacillus subtilis subsp. subtilis 168 were also determined. The results showed that the $\mathrm{LD}_{50}$ of $\mathrm{G} 7$ in turbot, tongue sole, and mice were $3.2 \times 10^{5} \mathrm{CFU} / \mathrm{g}, 3.2 \times 10^{5} \mathrm{CFU} / \mathrm{g}$, and $5.4 \times 10^{5} \mathrm{CFU} / \mathrm{g}$, respectively; the $\mathrm{LD}_{50}$ of NCIB $3610^{\mathrm{T}}$ in turbot and mice were $4.55 \times 10^{5} \mathrm{CFU} / \mathrm{g}$ and $6.27 \times 10^{5} \mathrm{CFU} / \mathrm{g}$, respectively; the $\mathrm{LD}_{50}$ of strain 168 in turbot and mice were $2.93 \times 10^{6} \mathrm{CFU} / \mathrm{g}$ and $8.45 \times 10^{6} \mathrm{CFU} / \mathrm{g}$, respectively. Turbot infected with G7 at the dose of $5 \times 10^{5} \mathrm{CFU} / \mathrm{g}$ exhibited severe skin ulcer/lesion and hemorrhage (Figure 5A). When infecting mice at the dose of 2.5 $\times 10^{7} \mathrm{CFU} / \mathrm{g}, \mathrm{G} 7, \mathrm{NCIB} 3610^{\mathrm{T}}$, and strain 168 all caused $100 \%$ mortality within $24 \mathrm{~h}$; G7-infected mice developed symptoms of shaking and arching of the back at $2 \mathrm{hpi}$, and secreting white substances from the eyes at $4 \mathrm{hpi}$; the mice began to die after 6 hpi (Figure 5B); moribund mice showed enlargement of spleen and congestion of liver (Figure 5C). When infecting mice at the dose of $2.5 \times 10^{6} \mathrm{CFU} / \mathrm{g}$, G7 and NCIB $3610^{\mathrm{T}}$ caused $70 \%$ and $60 \%$ mortality, respectively, with death beginning to occur on the third day, whereas strain 168 induced no mortality et al (100\% survival of the infected animal) (Figure S3). Tissue dissemination analysis showed that following muscle injection into turbot, G7 was detected in liver and spleen, with bacterial numbers increasing with time; strain 168 was also detected in fish tissues, however, the numbers of strain 168 were lower than G7 and decreased sharply with time (Figure 6A). Similar results were observed with bacterial recoveries from G7- and strain 168infected mice (Figure 6B). No bacteria were detected in the blood of the infected mice or fish.

\section{Intracellular Replication in Host Phagocytes}

Intracellular replication study showed that following incubation with RAW264.7, G7, NCIB $3610^{\mathrm{T}}$, and strain 168 were all detected inside the cells within $2 \mathrm{hpi}$. The intracellular numbers of G7 and $\mathrm{NCIB} 3610^{\mathrm{T}}$ increased with time, however, the number of G7 increased much faster and reached much higher amount than that of $\mathrm{NCIB} 3610^{\mathrm{T}}$, whereas no apparent intracellular replication of strain 168 was detected (Figure 7A). Consistently, confocal microscopy observed intracellular presence and replication of G7 in RAW264.7 (Figure 7B). Similar invasion and intracellular replication of G7 in turbot PBL were also observed (data not shown).

\section{Serum Resistance and Hemolytic Activity}

Following incubation with the sera of tongue sole, turbot, and mice, the survival rates of $\mathrm{G} 7$ were $70.38,76.3$, and $60.28 \%$, respectively; the survival rates of NCIB $3610^{\mathrm{T}}$ were $72.3,71.6$, and $58 \%$, respectively; the survival rates of strain 168 were 64.3 , 71.9 , and $51.5 \%$, respectively; whereas the survival rates of E. coli DH5 $\alpha$, a non-virulent laboratory strain, after the same serum treatment were 2.5, 1.6, and 0.8\%, respectively (Figure 8A). Hemolytic analysis indicated that G7 and NCIB $3610^{\mathrm{T}}$, but not strain 168, were able to cause lysis of rabbit red blood cells (Figure 8B). 


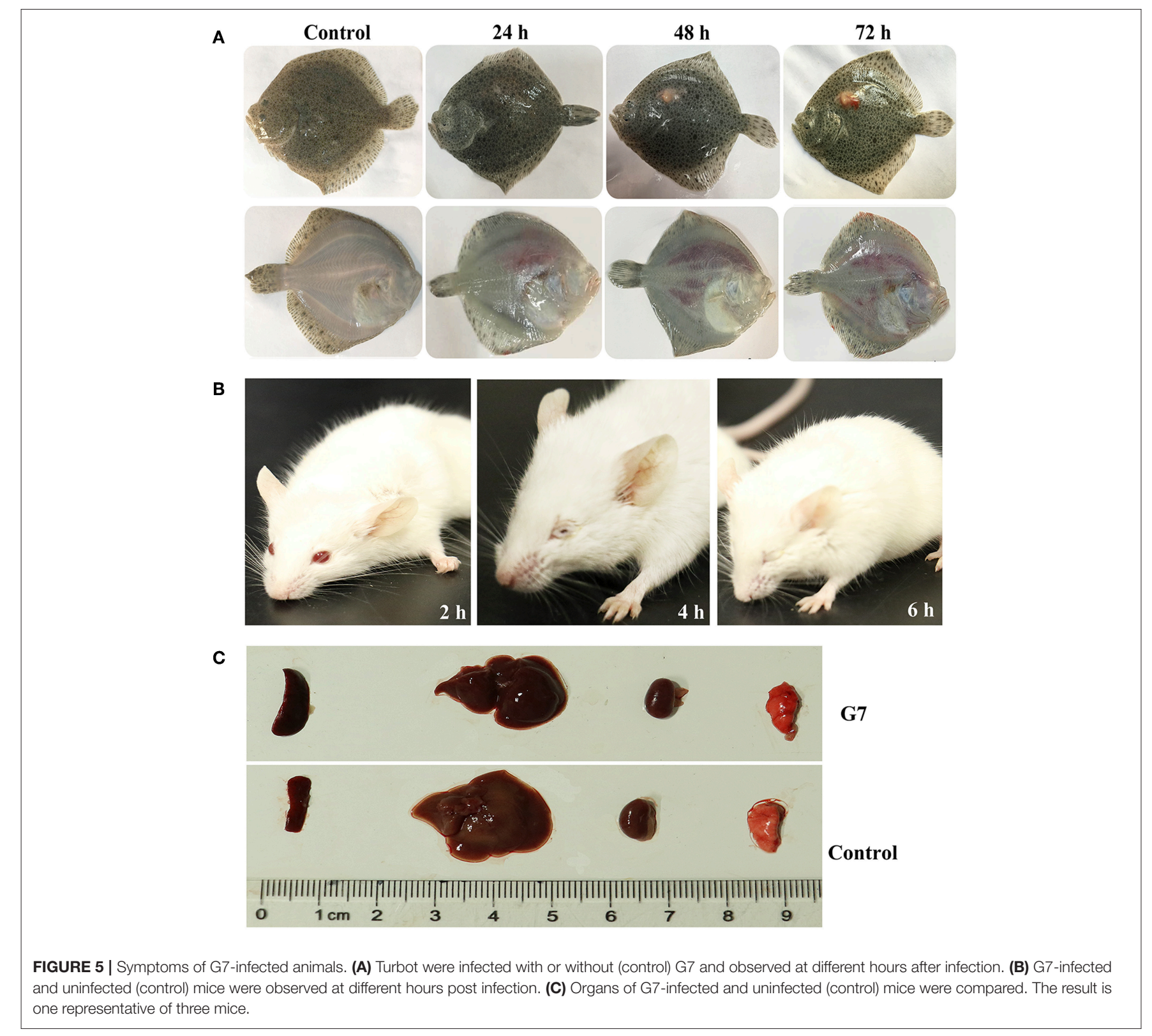

\section{DISCUSSION}

In this study, we examined the biological, genomic, and virulence characteristics of G7 from Iheya North hydrothermal field. Phylogenomic analysis indicated that G7 belongs to the B. subtilis subsp. subtilis species. It is of note that in the genome-based phylogenetic tree, the clade containing G7 was separated from that containing the pathogenic strains of $B$. anthracis str. Ames and $B$. cereus ATCC 14579, suggesting that G7 likely possesses some unique genetic characteristics that distinguish it from other pathogenic members of the Bacillus genus. Comparative genomic analysis between G7 and the B. subtilis subsp. subtilis wild type strain NCIB $3610^{\mathrm{T}}$ (Srivatsan et al., 2008) revealed that G7 contains many translocations, inversions, and insertions.
This observation, together with the fact that G7 is rich in mobile genetic elements such as integrases, transposases, and bacteriophage-related proteins, indicates that G7 genome may have undergone some genetic alterations via phage infection, horizontal gene transfer, and genetic reshuffling, which may explain why much more GIs were identified in the genome of G7 than in that of NCIB $3610^{\mathrm{T}}$. This hypothesis is in line with the thought that in oceanic environments, phages are an important factor in the transfer of small gene cassettes between hosts (Lindell et al., 2004). Compared to NCIB $3610^{\mathrm{T}}$, G7 possesses more specific genes belonging to the COG categories of K, T, S, X, and $\mathrm{I}$. The $\mathrm{K}$ and $\mathrm{T}$ genes have been found to be associated with the capacity of niche adaptation and regulation of metabolism and transporters for nutrient acquisition in marine bacteria 

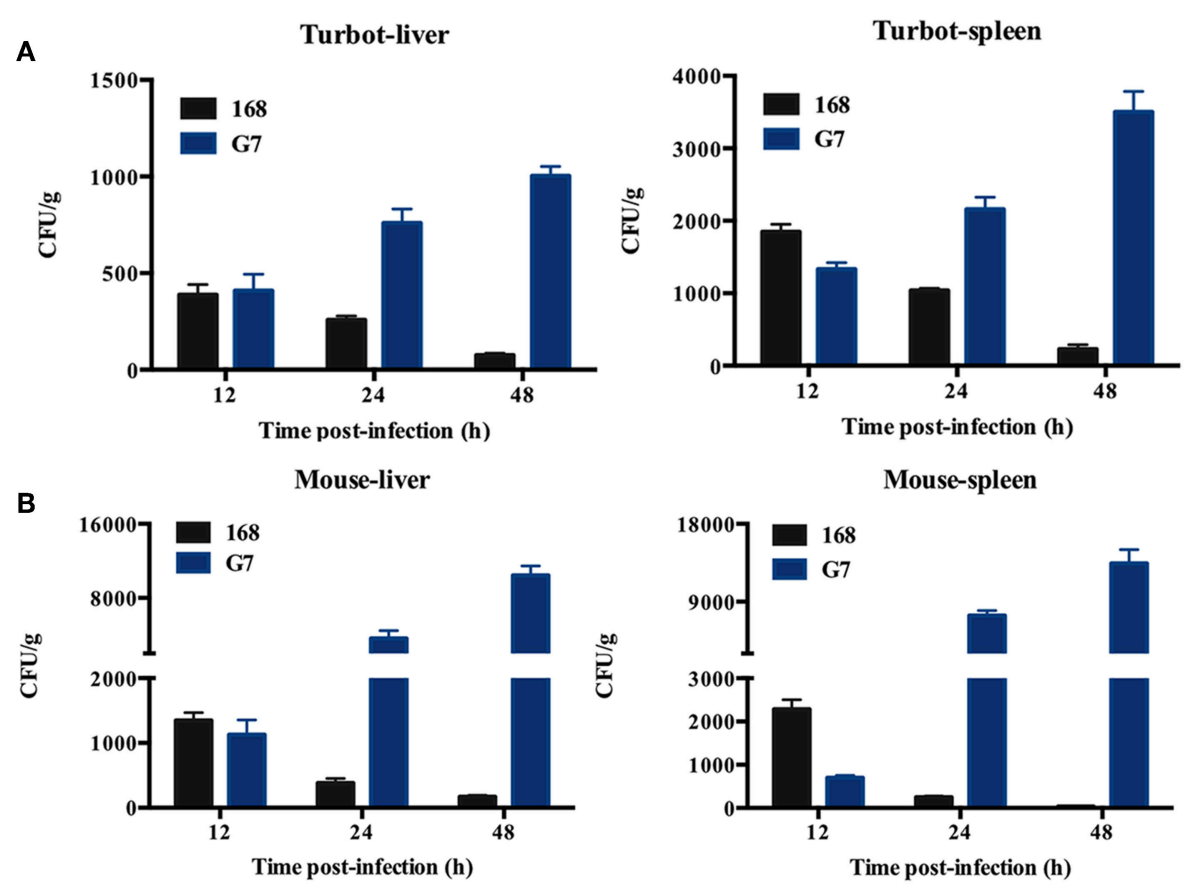

FIGURE 6 | Dissemination of G7 in fish and mice tissues. Turbot (A) and mice (B) were inoculated with G7 or strain 168 (control), and bacterial recovery from the tissues was determined at different time points. The results are the means of three experiments and shown as means \pm SEM.

(Thomas et al., 2008; Lauro et al., 2009). The S category of G7 contains mainly hypothetical protein genes in the GIs, and the high proportion of specific genes belonging to $\mathrm{X}$ (mobilome: prophages, transposons) in G7 is consistent with the observation of many mobile genetic elements in the genome. In Antarctica bacteria, the abundance of genes in the I category (lipid transport and metabolism) of COG was considered to be a survival strategy to increase bacterial membrane fluidity at low temperatures (Médigue et al., 2005). Compared to NCIB $3610^{\mathrm{T}}$, G7 also shows decrease in the genes involved in COG categories of F, G, H, L, and $\mathrm{O}$, which is similar to previous observations in other deepsea bacteria (Wang et al., 2008). The decrease of genes related to carbohydrate $(\mathrm{G})$, nucleotide $(\mathrm{F})$, and coenzyme $(\mathrm{H})$ transport and metabolism is consistent with the oligotrophic conditions of deep-sea environments (Pedersen, 1993), where many bacteria appear to derive energy primarily from amino acid metabolism, rather than from sugar fermentation (Bartlett, 2002; Hou et al., 2004).

To date, B. subtilis has been extensively studied, primarily as a model for cell differentiation and exploitation in the biotechnology industry (Hoa et al., 2001; Asgher et al., 2007). B. subtilis has received little clinical attention as it has been associated only with opportunistic infections of immunocompromised patients (Ihde and Armstrong, 1973; Reller, 1973). In our study, we found that G7 could replicate in eukaryotic cells and cause acute symptom and mortality in teleost and mice following artificial inoculation. NCIB $3610^{\mathrm{T}}$, the close homolog of G7, exhibited roughly similar capacities. It remains to be examined whether the clinical characteristics induced by
G7 were the result of bacterial pathogenicity. Compared to NCIB $3610^{\mathrm{T}}$, G7 showed slight but distinct differences in $\mathrm{LD}_{50}$, host lethality, and replication ability in phagocytic cells, however, the biological significance of these differences between the two strains remains to be investigated.

Previous reports showed that some virulent Bacillus specie possess certain capacities, notably secretion of virulent proteins such as hemolysin, protease, phospholipase, toxin, and cytotoxin (Dixon et al., 2000; Senesi and Ghelardi, 2010; Ramarao and Sanchis, 2013; Jeßberger et al., 2015), swimming and swarming motility (Senesi et al., 2010), and intracellular survival and escape (Dixon et al., 2000). In our study, genes associated with motility, toxicity, adhesion, invasion, immune escape, and intracellular survival are present in G7 genome. For motility, many genes related to flagellar assembly were found in G7. Previous studies showed that flagellum-mediated motility is important to allow bacteria to move toward favorable environments and for increasing pathogen-host interaction (La Ragione et al., 2000; Krukonis and DiRita, 2003; Dons et al., 2004; van Asten et al., 2004; Duan et al., 2013). In G7, in agreement with the presence of flagellar genes, the bacteria exhibited polar and lateral flagella and showed apparent swimming and swarming capacities. With respect to toxins, it has been reported that the hemolysin and enterococcal cytolysin of Bacillus species could act as tissue destructive/reactive proteins and damage the integrity of cellular plasma membrane (Baida and Kuzmin, 1996; Shankar et al., 2004; Senesi and Ghelardi, 2010). In G7, hemolysin III and cytolysin genes were identified, and G7 exhibited apparent hemolytic activity, suggesting that these genes may play a role in internal 


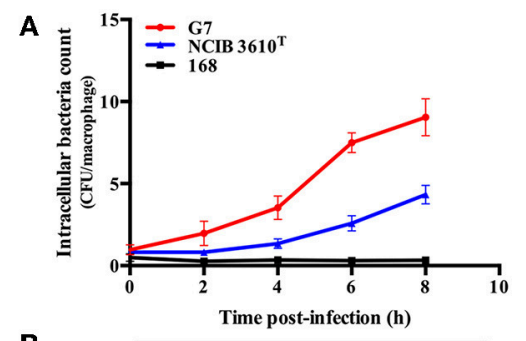

B

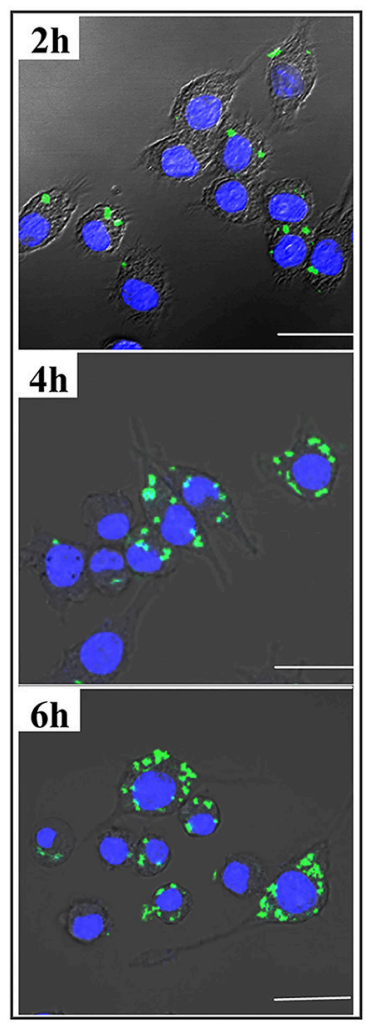

FIGURE 7 | Replication of G7 in macrophages. (A) RAW264.7 cells were infected with G7, NCIB $3610^{\top}$, and strain 168 for $2 \mathrm{~h}$, and extracellular bacteria were killed by antibiotics. The cells were cultured further for 2, 4, 6 , and $8 \mathrm{~h}$, and intracellular bacterial number was determined by plate count. The results are the means of three experiments and shown as means $\pm \mathrm{SEM}$. (B) Microscopic observation of RAW264.7 infected with G7 as above. G7 and RAW264.7 were stained with CFDA-SE (green) and Hoechst 33258 (blue), respectively. Bar, $10 \mu \mathrm{m}$.

tissue damage that led to the observed hemorrhage of G7-infected animals in our study. Although the virulence-associated genes with known functions are highly similar in G7 and NCIB $3610^{\mathrm{T}}$, G7 contains many more genomic alterations (translocations, inversions, and insertions) and twice the amount of GIs than NCIB $3610^{\mathrm{T}}$, and, more importantly, most GIs genes are G7specific and do not have orthologs in NCIB 3610T. These results suggest that in addition to the predicted virulence genes common to both G7 and NCIB $3610^{\mathrm{T}}$, the large amount of unique GI genes specific to G7 may also play a role in the lethality of G7 to fish and mice.

The ability of a pathogen to attach to host cells is essential to establish infection (Zhang and Stephens, 1992). In our

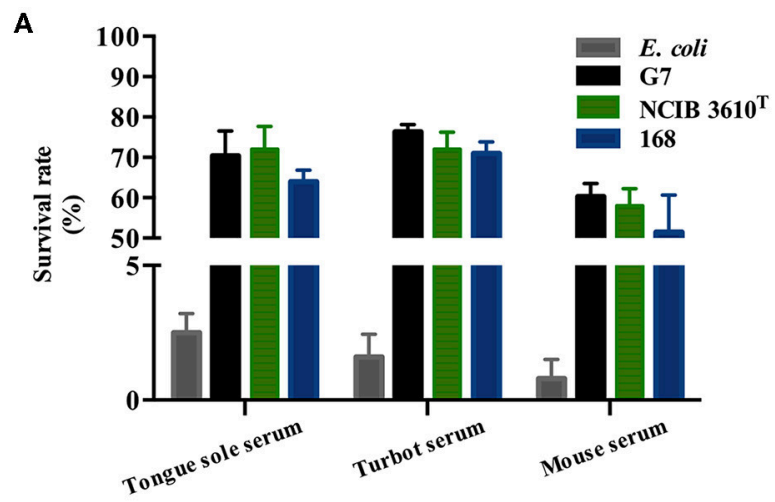

B

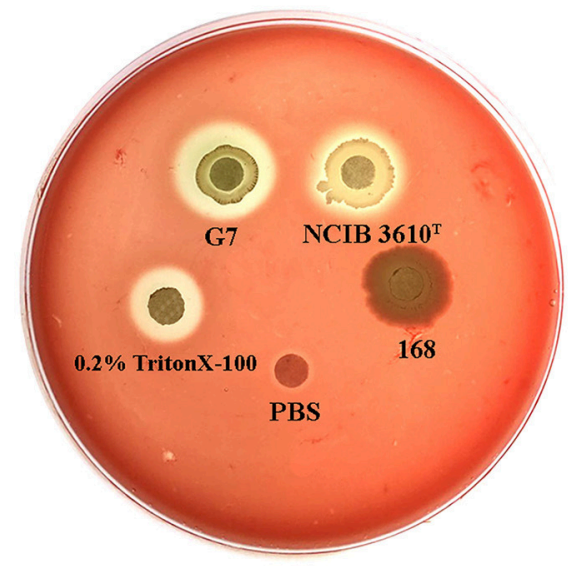

FIGURE 8 | Serum resistance (A) and hemolytic activity (B) of G7. (A) G7, $\mathrm{NCIB} 3610^{\top}$, strain 168, and Escherichia coli were incubated with or without (control) serum from tongue sole, turbot, or mouse, and bacterial survival was determined by plate count. The survival rate was expressed as (number of cells surviving serum treatment/number of cells in control treatment) $\times 100 \%$. The data are the means of three experiments and shown as means \pm SEM. (B) G7, NCIB $3610^{\top}$, strain 168, 0.2\% Triton X-100, and PBS were spotted onto the filter discs in rabbit blood agar plate, and the plate was observed for hemolytic halo after $24 \mathrm{~h}$ incubation.

study, we found that G7 possesses putative adhesion factors including $\mathrm{FbpA}, \mathrm{ClpC}$, and Hsp60, all which are known to mediate attachment to host cells (Garduño et al., 1998; Osanai et al., 2013). Once inside the host, the pathogen has to combat with host defense in various forms such as phagocytosisand complement-mediated killing. Reports have shown that $S$. pyogenes and $B$. anthracis were able to utilize their hyaluronic acid capsules to resist phagocytosis (Ashbaugh et al., 1998; Makino et al., 2002), and B. anthracis could also escape from complement killing by aid of its capsule (Lindberg, 1999). In the case of G7, it contains capsule genes and the genes of LplA1, LspA, PanD, PanC, SodA, and SodB, which are related to intracellular infection. In addition, G7 also possesses genes encoding enterobactin, mycobactin, pyoverdine, pyochelin, and Fe-transport operon, which are responsible for iron uptake (Strange et al., 2011; Cassat and Skaar, 2013; Poppe et al., 2018; Qi and Han, 2018). Being an essential nutrient, iron 
is required for successful bacterial survival in host cells. As a result, during infection, the bacteria have to exert various strategies to compete with the host for iron (Wilson et al., 2016). The presence of abundant iron acquisition genes as well as other genes involved in intracellular survival probably accounts at least in part for the capacity of the G7 to replicate in host phagocytes.

In conclusion, we investigated for the first time the virulence potential of a $B$. subtilis strain from deep-sea hydrothermal field. Our results showed that following artificial injection into lower and higher vertebrate animals, G7 was capable of tissue dissemination and inducing host mortality, but the underlying mechanism is not clear. The genome of G7 contains a large amount of genes encoding putative virulence factors as well as hypothetical proteins with unknown functions, however, whether these factors and proteins have actually contributed to the lethal effect observed with G7 remains to be investigated by future studies.

\section{ETHICS STATEMENT}

Experiments involving live animals conducted in this study were approved by the Ethics Committee of Institute of Oceanology, Chinese Academy of Sciences. All methods were carried out

\section{REFERENCES}

Altschul, S. F., Gish, W., Miller, W., Myers, E. W., and Lipman, D. J. (1990). Basic local alignment search tool. J. Mol. Biol. 215, 403-410. doi: $10.1016 / \mathrm{S} 0022-2836(05) 80360-2$

Asgher, M., Asad, M. J., Rahman, S. U., and Legge, R. L. (2007). A thermostable $\alpha$-amylase from a moderately thermophilic Bacillus subtilis strain for starch processing. J. Food Eng. 79, 950-955. doi: 10.1016/j.jfoodeng.2005.12.053

Ashbaugh, C. D., Warren, H. B., Carey, V. J., and Wessels, M. R. (1998). Molecular analysis of the role of the group A streptococcal cysteine protease, hyaluronic acid capsule, and $\mathrm{M}$ protein in a murine model of human invasive soft-tissue infection. J. Clin. Invest. 102, 550-560. doi: 10.1172/JCI3065

Ashburner, M., Ball, C. A., Blake, J. A., Botstein, D., Butler, H., Cherry, J. M., et al. (2000). Gene ontology: tool for the unification of biology. The Gene Ontology Consortium. Nat. Genet. 25, 25-29. doi: 10.1038/75556

Baida, G. E., and Kuzmin, N. P. (1996). Mechanism of action of hemolysin III from Bacillus cereus. Biochim. Biophys. Acta. 1284, 122-124. doi: 10.1016/S0005-2736(96)00168-X

Bairoch, A., and Apweiler, R. (2000). The SWISS-PROT protein sequence database and its supplement TrEMBL in 2000. Nucleic Acids Res. 28, 45-48. doi: $10.1093 /$ nar $/ 28.1 .45$

Bartlett, D. H. (2002). Pressure effects on in vivo microbial processes. Biochim. Biophys. Acta. 1595, 367-381. doi: 10.1016/S0167-4838(01)00357-0

Batzke, A., Engelen, B., Sass, H., and Cypionka, H. (2007). Phylogenetic and physiological diversity of cultured deep-biosphere bacteria from equatorial Pacific Ocean and Peru Margin sediments. Geomicrobiol. J. 24, 261-273. doi: $10.1080 / 01490450701456453$

Benson, G. (1999). Tandem repeats finder: a program to analyze DNA sequences. Nucleic Acids Res. 27, 573-580. doi: 10.1093/nar/27.2.573

Berlin, K., Koren, S., Chin, C. S., Drake, J. P., Landolin, J. M., and Phillippy, A. M. (2015). Assembling large genomes with single-molecule sequencing and locality-sensitive hashing. Nat. Biotechnol. 33, 623-630. doi: 10.1038/nbt.3238

Besemer, J., Lomsadze, A., and Borodovsky, M. (2001). GeneMarkS: a self-training method for prediction of gene starts in microbial genomes. Implications for in accordance with the relevant guidelines, including any relevant details.

\section{AUTHOR CONTRIBUTIONS}

JZ and Q-LS obtained the deep sea sample and performed bacterial isolation. LS and H-JG conceived and designed the experiments. H-JG and J-CL performed the experiments and analyzed the data. H-JG and LS wrote the paper.

\section{FUNDING}

This work was supported by the grants from The Strategic Priority Research Program of the Chinese Academy of Sciences (XDA22050403), Qingdao National Laboratory for Marine Science and Technology (QNLM2016ORP0309), Shandong Major Science and Technology Innovation Project (2018SDKJ0302), and the Taishan Scholar Program of Shandong Province.

\section{SUPPLEMENTARY MATERIAL}

The Supplementary Material for this article can be found online at: https://www.frontiersin.org/articles/10.3389/fcimb. 2019.00183/full\#supplementary-material

finding sequence motifs in regulatory regions. Nucleic Acids Res. 29, 2607-2618. doi: $10.1093 /$ nar/29.12.2607

Bisno, A. L., Brito, M. O., and Collins, C. M. (2003). Molecular basis of group A streptococcal virulence. Lancet. Infect. Dis. 3, 191-200. doi: 10.1016/S1473-3099(03) 00576-0

Brown, K. L. (2000). Control of bacterial spores. Br. Med. Bull. 56, 158-171. doi: 10.1258/0007142001902860

Caputo, A., Merhej, V., Georgiades, K., Fournier, P. E., Croce, O., Robert, C., et al. (2015). Pan-genomic analysis to redefine species and subspecies based on quantum discontinuous variation: the Klebsiella paradigm. Bio. Direct. 10:55. doi: 10.1186/s13062-015-0085-2

Cassat, J. E., and Skaar, E. P. (2013). Iron in infection and immunity. Cell Host Microbe 13, 509-519. doi: 10.1016/j.chom.2013.04.010

Chen, L., Yang, J., Yu, J., Yao, Z., Sun, L., Shen, Y., et al. (2005). VFDB: a reference database for bacterial virulence factors. Nucleic Acids Res. 33(Database issue), D325-328. doi: 10.1093/nar/gki008

Cote, C. K., Heffron, J. D., Bozue, J. A., and Welkos, S. L. (2015). "Chapter 102 - Bacillus anthracis and other Bacillus species A2 - Tang, Yi-Wei," in Molecular Medical Microbiology, 2nd Edn, eds. M. Sussman, D. Liu, I. Poxton, and J. Schwartzman. (Boston, MA: Academic Press), 1789-1844. doi: 10.1016/B978-0-12-397169-2.00102-5

D’Hondt, S., Jorgensen, B. B., Miller, D. J., Batzke, A., Blake, R., Cragg, B. A., et al. (2004). Distributions of microbial activities in deep subseafloor sediments. Science 306, 2216-2221. doi: 10.1126/science.1101155

Dietert, K., Gutbier, B., Wienhold, S. M., Reppe, K., Jiang, X., Yao, L., et al. (2017). Spectrum of pathogen- and model-specific histopathologies in mouse models of acute pneumonia. PLoS ONE 12:e0188251. doi: 10.1371/journal.pone.0188251

Dixon, T. C., Fadl, A. A., Koehler, T. M., Swanson, J. A., and Hanna, P. C. (2000). Early Bacillus anthracis-macrophage interactions: intracellular survival survival and escape. Cell. Microbiol. 2, 453-463. doi: 10.1046/j.1462-5822.2000.00067.x

Dons, L., Eriksson, E., Jin, Y., Rottenberg, M. E., Kristensson, K., Larsen, C. N., et al. (2004). Role of flagellin and the two-component CheA/CheY system of Listeria monocytogenes in host cell invasion and 
virulence. Infect. Immun. 72, 3237-3244. doi: 10.1128/IAI.72.6.3237-324 4.2004

Duan, Q., Zhou, M., Zhu, L., and Zhu, G. (2013). Flagella and bacterial pathogenicity. J. Basic Microbiol. 53, 1-8. doi: 10.1002/jobm.201100335

Edgar, R. C. (2004). MUSCLE: multiple sequence alignment with high accuracy and high throughput. Nucleic Acids Res. 32, 1792-1797. doi: $10.1093 /$ nar/gkh340

Euzéby, J. P. (1997). List of bacterial names with standing in nomenclature: a folder available on the internet. Int. J. Syst. Bacteriol. 47, 590-592. doi: 10.1099/00207713-47-2-590

Fang, J., Kato, C., Runko, G. M., Nogi, Y., Hori, T., Li, J., et al. (2017). Predominance of viable spore-forming piezophilic bacteria in high-pressure enrichment cultures from $\sim 1.5$ to $2.4 \mathrm{~km}$ deep coal-bearing sediments below the ocean floor. Front. Microbiol. 8:137. doi: 10.3389/fmicb.201 7.00137

Galéron, J. (2014). “Deep-sea Environment," in Deep Marine Mineral Resources, eds. Y. Fouquet and D. Lacroix. (Dordrecht: Springer Netherlands), 41-54. doi: 10.1007/978-94-017-8563-1_2

Gardner, P. P., Daub, J., Tate, J. G., Nawrocki, E. P., Kolbe, D. L., Lindgreen, S., et al. (2009). Rfam: updates to the RNA families database. Nucleic Acids Res. 37(Database issue), D136-D140. doi: 10.1093/nar/ gkn766

Garduño, R. A., Garduño, E., and Hoffman, P. S. (1998). Surface-associated hsp60 chaperonin of Legionella pneumophila mediates invasion in a HeLa cell model. Infect. Immun. 66, 4602-4610.

Hoa, T. T., Duc, L. H., Isticato, R., Baccigalupi, L., Ricca, E., Van, P. H., et al. (2001). Fate and dissemination of Bacillus subtilis spores in a murine model. Appl. Environ. Microbiol. 67, 3819-3823. doi: 10.1128/AEM.67.9.3819-3823.2001

Hoffmaster, A. R., Hill, K. K., Gee, J. E., Marston, C. K., De, B. K., Popovic, T., et al. (2006). Characterization of Bacillus cereus isolates associated with fatal pneumonias: strains are closely related to Bacillus anthracis and harbor B. anthracis virulence genes. J. Clin. Microbiol. 44, 3352-3360. doi: 10.1128/JCM.00561-06

Hou, C. T., Labeda, D. P., and Rooney, A. (2005). Evaluation of microbial strains for linoleic acid hydroxylation and reclassification of strain ALA2. Antonie Van Leeuwenhoek 88, 167-171. doi: 10.1007/s10482-005-3369-1

Hou, S., Saw, J. H., Lee, K. S., Freitas, T. A., Belisle, C., Kawarabayasi, Y., et al. (2004). Genome sequence of the deep-sea $\gamma$-proteobacterium Idiomarina loihiensis reveals amino acid fermentation as a source of carbon and energy. Pro. Natl. Acad. Sci. U.S.A. 101, 18036-18041. doi: 10.1073/pnas.0407638102

Hsiao, W., Wan, I., Jones, S. J., and Brinkman, F. S. (2003). IslandPath: aiding detection of genomic islands in prokaryotes. Bioinformatics 19, 418-420. doi: 10.1093/bioinformatics/btg004

Hu, Y. H., Li, Y. X., and Sun, L. (2014). Edwardsiella tarda Hfq: impact on host infection and global protein expression. Vet. res. 45, 23-23. doi: 10.1186/1297-9716-45-23

Huang, Y., Niu, B., Gao, Y., Fu, L., and Li, W. (2010). CD-HIT Suite: a web server for clustering and comparing biological sequences. Bioinformatics 26, 680-682. doi: 10.1093/bioinformatics/btq003

Ihde, D. C., and Armstrong, D. (1973). Clinical spectrum of infection due to Bacillus species. Am. J. Med. 55, 839-845. doi: 10.1016/0002-9343(73)90266-0

Ivanova, E. P., Vysotskii, M. V., Svetashev, V. I., Nedashkovskaya, O. I., Gorshkova, N. M., Mikhailov, V. V., et al. (1999). Characterization of Bacillus strains of marine origin. Int. Microbiol. 2, 267-271.

Jeßberger, N., Krey, V. M., Rademacher, C., Bohm, M. E., Mohr, A. K., EhlingSchulz, M., et al. (2015). From genome to toxicity: a combinatory approach highlights the complexity of enterotoxin production in Bacillus cereus. Front. Microbiol. 6:560. doi: 10.3389/fmicb.2015.00560

Kanehisa, M., Goto, S., Kawashima, S., Okuno, Y., and Hattori, M. (2004). The KEGG resource for deciphering the genome. Nucleic Acids Res. 32(Database issue), D277-D280. doi: 10.1093/nar/gkh063

Khasawneh, A. F., Al-Hadidi, K. A., Aburjai, T. A., and Obeidat, F. N. (2015). Acute and subacute (20-d) oral dose toxicity study of modified fluoroquinolone compound 6C in BALB/c mice. Toxin Rev. 34, 129-135. doi: $10.3109 / 15569543.2015 .1076483$

Krukonis, E. S., and DiRita, V. J. (2003). From motility to virulence: Sensing and responding to environmental signals in Vibrio cholerae. Curr. Opin. Microbiol. 6, 186-190. doi: 10.1016/S1369-5274(03)00032-8
Krzywinski, M., Schein, J., Birol, I., Connors, J., Gascoyne, R., Horsman, D., et al. (2009). Circos: an information aesthetic for comparative genomics. Genome Res. 19, 1639-1645. doi: 10.1101/gr.092759.109

Kurata, A., Matsumoto, M., Kobayashi, T., Deguchi, S., and Kishimoto, N. (2015). Hyaluronate lyase of a deep-sea Bacillus niacini. Mar. Biotechnol. 17, 277-284. doi: 10.1007/s10126-015-9618-z

Kurtz, S., Phillippy, A., Delcher, A. L., Smoot, M., Shumway, M., Antonescu, C., et al. (2004). Versatile and open software for comparing large genomes. Genome Biol. 5:R12. doi: 10.1186/gb-2004-5-2-r12

La Ragione, R. M., Sayers, A. R., and Woodward, M. J. (2000). The role of fimbriae and flagella in the colonization, invasion and persistence of Escherichia coli O78:K80 in the day-old-chick model. Epidemiol. Infect. 124, 351-363. doi: 10.1017/S0950268899004045

Labreuche, Y., Le Roux, F., Henry, J., Zatylny, C., Huvet, A., Lambert, C., et al. (2010). Vibrio aestuarianus zinc metalloprotease causes lethality in the Pacific oyster Crassostrea gigas and impairs the host cellular immune defenses. Fish Shellfish Immunol. 29, 753-758. doi: 10.1016/j.fsi.2010.07.007

Lagesen, K., Hallin, P., Rødland, E. A., Staerfeldt, H. H., Rognes, T., and Ussery, D. W. (2007). RNAmmer: consistent and rapid annotation of ribosomal RNA genes. Nucleic Acids Res. 35, 3100-3108. doi: 10.1093/nar/gkm160

Lauro, F. M., McDougald, D., Thomas, T., Williams, T. J., Egan, S., Rice, S., et al. (2009). The genomic basis of trophic strategy in marine bacteria. Pro. Natl. Acad. Sci. U.S.A. 106, 15527-15533. doi: 10.1073/pnas.0903507106

Li, W., Jaroszewski, L., and Godzik, A. (2002). Tolerating some redundancy significantly speeds up clustering of large protein databases. Bioinformatics 18, 77-82. doi: 10.1093/bioinformatics/18.1.77

Lindberg, A. A. (1999). Polyosides (encapsulated bacteria). C. R. Acad. Sci. Ser. III 322, 925-932. doi: 10.1016/S0764-4469(00)87188-7

Lindell, D., Sullivan, M. B., Johnson, Z. I., Tolonen, A. C., Rohwer, F., and Chisholm, S. W. (2004). Transfer of photosynthesis genes to and from Prochlorococcus viruses. Pro. Natl. Acad. Sci. U.S.A. 101, 11013-11018. doi: 10.1073/pnas.0401526101

Liu, B., Wang, Y., and Zhang, X. (2006). Characterization of a recombinant maltogenic amylase from deep sea thermophilic Bacillus sp. WPD616. Enzyme Microb. Technol. 39, 805-810. doi: 10.1016/j.enzmictec.2006.01.003

Liu, C. S., Sun, Y., Hu, Y. H., and Sun, L. (2010). Identification and analysis of a CpG motif that protects turbot (Scophthalmus maximus) against bacterial challenge and enhances vaccine-induced specific immunity. Vaccine 28, 4153-4161. doi: 10.1016/j.vaccine.2010.04.016

Logan, N. A. (2012). Bacillus and relatives in foodborne illness. J. Appl. Microbiol. 112, 417-429. doi: 10.1111/j.1365-2672.2011.05204.x

Lowe, T. M., and Eddy, S. R. (1997). tRNAscan-SE: a program for improved detection of transfer RNA genes in genomic sequence. Nucleic Acids Res. 25, 955-964. doi: 10.1093/nar/25.5.955

Makino, S., Watarai, M., Cheun, H. I., Shirahata, T., and Uchida, I. (2002). Effect of the lower molecular capsule released from the cell surface of Bacillus anthracis on the pathogenesis of anthrax. J. Infect. Dis. 186, 227-233. doi: 10.1086/341299

Marteinsson, V., Birrien, J. L., Jeanthon, C., and Prieur, D. (1996). Numerical taxonomic study of thermophilic Bacillus isolated from three geographically separated deep-sea hydrothermal vents. FEMS Microbiol. Ecol. 21, 255-266. doi: 10.1111/j.1574-6941.1996.tb00122.x

Médigue, C., Krin, E., Pascal, G., Barbe, V., Bernsel, A., Bertin, P. N., et al. (2005). Coping with cold: The genome of the versatile marine Antarctica bacterium Pseudoalteromonas haloplanktis TAC125. Genome Res. 15, 1325-1335. doi: 10.1101/gr.4126905

Mi, Z. H., Yu, Z. C., Su, H. N., Wang, L., Chen, X. L., Pang, X., et al. (2015). Physiological and genetic analyses reveal a mechanistic insight into the multifaceted lifestyles of Pseudoalteromonas sp. SM9913 adapted to the deepsea sediment. Environ. Microbiol. 17, 3795-3806. doi: 10.1111/1462-2920.12823

Nielsen-LeRoux, C., Gaudriault, S., Ramarao, N., Lereclus, D., and Givaudan, A. (2012). How the insect pathogen bacteria Bacillus thuringiensis and Xenorhabdus/Photorhabdus occupy their hosts. Curr. Opin. Microbiol. 15, 220-231. doi: 10.1016/j.mib.2012.04.006

O'Riordan, M., Moors, M. A., and Portnoy, D. A. (2003). Listeria intracellular growth and virulence require host-derived lipoic acid. Science 302, 462-464. doi: $10.1126 /$ science. 1088170

Osanai, A., Li, S. J., Asano, K., Sashinami, H., Hu, D. L., and Nakane, A. (2013). Fibronectin-binding protein, FbpA, is the adhesin responsible for 
pathogenesis of Listeria monocytogenes infection. Microbiol. Immunol. 57, 253-262. doi: 10.1111/1348-0421.12030

Pathak, R., Rathor, N., Garima, K., Sharma, N. K., Singh, P., Varma-Basil, M., et al. (2015). lspA gene of Mycobacterium tuberculosis co-transcribes with Rv1540 and induced by surface and acidic stress. Gene 560, 57-62. doi: 10.1016/j.gene.2015.01.061

Pedersen, K. (1993). The deep subterranean biosphere. Earth Sci. Rev. 34, 243-260. doi: 10.1016/0012-8252(93)90058-F

Poppe, J., Reichelt, J., and Blankenfeldt, W. (2018). Pseudomonas aeruginosa pyoverdine maturation enzyme PvdP has a noncanonical domain architecture and affords insight into a new subclass of tyrosinases. J. Biol. Chem. 293, 14926-14936. doi: 10.1074/jbc.RA118.002560

Price, N. P., Rooney, A. P., Swezey, J. L., Perry, E., and Cohan, F. M. (2007). Mass spectrometric analysis of lipopeptides from Bacillus strains isolated from diverse geographical locations. FEMS Microbiol. Lett. 271, 83-89. doi: 10.1111/j.1574-6968.2007.00702.x

Qi, B., and Han, M. (2018). Microbial siderophore enterobactin promotes mitochondrial iron uptake and development of the host via interaction with ATP synthase. Cell 175, 571-582. doi: 10.1016/j.cell.2018.07.032

Ramarao, N., and Sanchis, V. (2013). The pore-forming haemolysins of Bacillus cereus: a review. Toxins 5, 1119-1139. doi: 10.3390/toxins5061119

Rampini, S. K., Selchow, P., Keller, C., Ehlers, S., Böttger, E. C., and Sander, P. (2008). LspA inactivation in Mycobacterium tuberculosis results in attenuation without affecting phagosome maturation arrest. Microbiology 154(Pt 10), 2991-3001. doi: 10.1099/mic.0.2008/018895-0

Reller, L. B. (1973). Endocarditis caused by Bacillus subtilis. Am. J. Clin. Pathol. 60, 714-718. doi: 10.1093/ajcp/60.5.714

Richter, M., and Rosselló-Móra, R. (2009). Shifting the genomic gold standard for the prokaryotic species definition. Pro. Natl. Acad. Sci. U.S.A. 106, 19126-19131. doi: 10.1073/pnas.0906412106

Sadosky, A. B., Wilson, J. W., Steinman, H. M., and Shuman, H. A. (1994). The iron superoxide dismutase of Legionella pneumophila is essential for viability. J. Bacteriol. 176, 3790-3799. doi: 10.1128/jb.176.12.3790-3799.1994

Saha, S., Bridges, S., Magbanua, Z. V., and Peterson, D. G. (2008). Empirical comparison of ab initio repeat finding programs. Nucleic Acids Res. 36, 2284-2294. doi: 10.1093/nar/gkn064

Sass, A. M., McKew, B. A., Sass, H., Fichtel, J., Timmis, K. N., and McGenity, T. J. (2008). Diversity of Bacillus-like organisms isolated from deep-sea hypersaline anoxic sediments. Saline Syst. 4:8. doi: 10.1186/1746-1448-4-8

Schoeni, J. L., and Wong, A. C. (2005). Bacillus cereus food poisoning and its toxins. J. Food Prot. 68, 636-648. doi: 10.4315/0362-028X-68.3.636

Senesi, S., and Ghelardi, E. (2010). Production, secretion and biological activity of Bacillus cereus enterotoxins. Toxins 2, 1690-1703. doi: 10.3390/toxins2071690

Senesi, S., Salvetti, S., Celandroni, F., and Ghelardi, E. (2010). Features of Bacillus cereus swarm cells. Res. Microbiol. 161, 743-749. doi: 10.1016/j.resmic.2010.10.007

Shankar, N., Coburn, P., Pillar, C., Haas, W., and Gilmore, M. (2004). Enterococcal cytolysin: activities and association with other virulence traits in a pathogenicity island. Int. J. Med. Microbiol. 293, 609-618. doi: 10.1078/1438-4221-00301

Smith, I. (2003). Mycobacterium tuberculosis pathogenesis and molecular determinants of virulence. Clin. Microbiol. Rev. 16, 463-496. doi: 10.1128/CMR.16.3.463-496.2003

Spencer, R. C. (2003). Bacillus anthracis. J. Clin. Pathol. 56, 182-187. doi: $10.1136 /$ jcp.56.3.182

Srivatsan, A., Han, Y., Peng, J., Tehranchi, A. K., Gibbs, R., Wang, J. D., et al. (2008). High-precision, whole-genome sequencing of laboratory strains facilitates genetic studies. PLoS Genet. 4:e1000139. doi: 10.1371/journal.pgen.1000139

Strange, H. R., Zola, T. A., and Cornelissen, C. N. (2011). The fbpABC operon is required for Ton-independent utilization of xenosiderophores by Neisseria gonorrhoeae strain FA19. Infect. Immun. 79, 267-278. doi: 10.1128/IAI.00807-10

Sui, Z. H., Xu, H., Wang, H., Jiang, S., Chi, H., and Sun, L. (2017). Intracellular trafficking pathways of Edwardsiella tarda: from Clathrin- and Caveolinmediated endocytosis to endosome and lysosome. Front. Cell. Infect. Microbiol. 7:400. doi: 10.3389/fcimb.2017.00400

Sun, Q. L., and Sun, L. (2016). Description of Domibacillus iocasae sp. nov., isolated from deep-sea sediment, and emended description of the genus Domibacillus. Int. J. Syst. Evol. Microbiol. 66, 982-987. doi: 10.1099/ijsem.0.0 00823
Sun, Q. L., Wang, M. Q., and Sun, L. (2015). Characteristics of the cultivable bacteria from sediments associated with two deep-sea hydrothermal vents in Okinawa Trough. World J. Microbiol. Biotechnol. 31, 2025-2037. doi: 10.1007/s11274-015-1953-8

Sun, Y. Y., Chi, H., and Sun, L. (2016). Pseudomonas fluorescens filamentous hemagglutinin, an iron-regulated protein, is an important virulence factor that modulates bacterial pathogenicity. Front. Microbiol. 7:1320. doi: $10.3389 /$ fmicb. 2016.01320

Tatusov, R. L., Fedorova, N. D., Jackson, J. D., Jacobs, A. R., Kiryutin, B., Koonin, E. V., et al. (2003). The COG database: an updated version includes eukaryotes. BMC Bioinf. 4:41. doi: 10.1186/1471-2105-4-41

Thomas, T., Evans, F. F., Schleheck, D., Mai-Prochnow, A., Burke, C., Penesyan, A., et al. (2008). Analysis of the Pseudoalteromonas tunicata genome reveals properties of a surface-associated life style in the marine environment. PLoS ONE 3:e3252. doi: 10.1371/journal.pone.0003252

Tollefson, J. (2014). China plunges into ocean research. Nature, 506:276. doi: $10.1038 / 506276 a$

Valiente Moro, C., Tran, F. H., Raharimalala, F. N., Ravelonandro, P., and Mavingui, P. (2013). Diversity of culturable bacteria including Pantoea in wild mosquito Aedes albopictus. BMC Microbiol. 13:70. doi: 10.1186/1471-2180-13-70

van Asten, F. J., Hendriks, H. G., Koninkx, J. F., and van Dijk, J. E. (2004). Flagellamediated bacterial motility accelerates but is not required for Salmonella serotype Enteritidis invasion of differentiated Caco-2 cells. Int. J. Med. Microbiol. 294, 395-399. doi: 10.1016/j.ijmm.2004.07.012

Wang, C., Hu, Y. H., Sun, B. G., Li, J., and Sun, L. (2013). Edwardsiella tarda Ivy, a lysozyme inhibitor that blocks the lytic effect of lysozyme and facilitates host infection in a manner that is dependent on the conserved cysteine residue. Infect. Immun. 81, 3527-3533. doi: 10.1128/IAI.00503-13

Wang, F., Wang, J., Jian, H., Zhang, B., Li, S., Wang, F., et al. (2008). Environmental adaptation: genomic analysis of the piezotolerant and psychrotolerant deepsea iron reducing bacterium Shewanella piezotolerans WP3. PLoS ONE 3:e1937. doi: 10.1371/annotation/744d7c8d-db8a-4ad4-aec5-62549b1dbefe

Wang, H. R., Hu, Y. H., Zhang, W. W., and Sun, L. (2009). Construction of an attenuated Pseudomonas fluorescens strain and evaluation of its potential as a cross-protective vaccine. Vaccine 27, 4047-4055. doi: 10.1016/j.vaccine.2009.04.023

Wen, J., Ren, C., Huang, N., Liu, Y., and Zeng, R. (2015). Draft genome of bagasse-degrading bacteria Bacillus aryabhattai GZ03 from deep sea water. Mar. Genom. 19, 13-14. doi: 10.1016/j.margen.2014.11.004

Wilson, B. R., Bogdan, A. R., Miyazawa, M., Hashimoto, K., and Tsuji, Y. (2016). Siderophores in iron metabolism: from mechanism to therapy potential. Trends Mol. Med. 22, 1077-1090. doi: 10.1016/j.molmed.2016.10.005

Xu, P., Li, W. J., Tang, S. K., Zhang, Y. Q., Chen, G. Z., Chen, H. H., et al. (2005). Naxibacter alkalitolerans gen. nov., sp. nov., a novel member of the family 'Oxalobacteraceae' isolated from China. Int. J. Syst. Evol. Microbiol. 55(Pt 3), 1149-1153. doi: 10.1099/ijs.0.63407-0

Zahrt, T. C., and Deretic, V. (2001). Mycobacterium tuberculosis signal transduction system required for persistent infections. Pro. Natl. Acad. Sci. U.S.A. 98, 12706-12711. doi: 10.1073/pnas.221272198

Zahrt, T. C., Wozniak, C., Jones, D., and Trevett, A. (2003). Functional analysis of the Mycobacterium tuberculosis MprAB two-component signal transduction system. Infect. Immun. 71, 6962-6970. doi: 10.1128/IAI.71.12.6962-6970.2003

Zhang, J. P., and Stephens, R. S. (1992). Mechanism of C. trachomatis attachment to eukaryotic host cells. Cell 69, 861-869. doi: 10.1016/0092-8674(92)90296-O

Zhou, Z. J., Sun, B. G., and Sun, L. (2015). Edwardsiella tarda Sip1: a seruminduced zinc metalloprotease that. is essential to serum resistance and host infection. Vet. Microbiol. 177, 332-340. doi: 10.1016/j.vetmic.2015.03.030

Conflict of Interest Statement: The authors declare that the research was conducted in the absence of any commercial or financial relationships that could be construed as a potential conflict of interest.

Copyright (C) 2019 Gu, Sun, Luo, Zhang and Sun. This is an open-access article distributed under the terms of the Creative Commons Attribution License (CC BY). The use, distribution or reproduction in other forums is permitted, provided the original author(s) and the copyright owner(s) are credited and that the original publication in this journal is cited, in accordance with accepted academic practice. No use, distribution or reproduction is permitted which does not comply with these terms. 